AperTO - Archivio Istituzionale Open Access dell'Università di Torino

\title{
Amodiaquine analogues containing NO-donor substructures: Synthesis and their preliminary evaluation as potential tools in the treatment of cerebral malaria
}

\section{This is the author's manuscript}

Original Citation:

Availability:

This version is available http://hdl.handle.net/2318/88173

since

Published version:

DOI:10.1016/j.ejmech.2011.02.029

Terms of use:

Open Access

Anyone can freely access the full text of works made available as "Open Access". Works made available under a Creative Commons license can be used according to the terms and conditions of said license. Use of all other works requires consent of the right holder (author or publisher) if not exempted from copyright protection by the applicable law. 


\section{(3) \\ UNIVERSITÀ DEGLI STUDI DI TORINO}

This Accepted Author Manuscript (AAM) is copyrighted and published by Elsevier. It is posted here by agreement between Elsevier and the University of Turin. Changes resulting from the publishing process - such as editing, corrections, structural formatting, and other quality control mechanisms - may not be reflected in this version of the text. The definitive version of the text was subsequently published in [European Journal of Medicinal Chemistry 46 (2011) 1757e1767, 22 February 2011, doi:10.1016/j.ejmech.2011.02.029].

You may download, copy and otherwise use the AAM for non-commercial purposes provided that your license is limited by the following restrictions:

(1) You may use this AAM for non-commercial purposes only under the terms of the CC-BY-NC-ND license.

(2) The integrity of the work and identification of the author, copyright owner, and publisher must be preserved in any copy.

(3) You must attribute this AAM in the following format: Creative Commons BY-NC-ND license (http://creativecommons.org/licenses/by-nc-nd/4.0/deed.en), [+ Digital Object Identifier link to the published journal article on Elsevier's ScienceDirect ${ }^{\circledR}$ platform $]$ 


\title{
Amodiaquine analogues containing NO-donor substructures: synthesis and their preliminary evaluation as potential tools in the treatment of cerebral malaria
}

Massimo Bertinaria $^{\mathrm{a}, \uparrow}$, Stefano Guglielmo ${ }^{\mathrm{a}, \uparrow}$, Barbara Rolando ${ }^{\mathrm{a}}$, Marta Giorgis ${ }^{\mathrm{a}}$, Cristina Aragno ${ }^{\mathrm{a}}$, Roberta Fruttero $^{\mathrm{a}}$, Alberto Gasco $^{\mathrm{a},{ }^{*}}$, Silvia Parapini $^{\mathrm{b}}$, Donatella Taramelli ${ }^{\mathrm{b}}$, Yuri C. Martins ${ }^{\mathrm{c}}$, Leonardo J. M. Carvalho ${ }^{c}$

${ }^{a}$ Dipartimento di Scienza e Tecnologia del Farmaco, Via P. Giuria 9, I-10125 Torino, Italy

${ }^{b}$ Dipartimento di Sanità Pubblica-Microbiologia-Virologia, Università degli Studi di Milano, Via Pascal 36, 20133 Milano, Italy

${ }^{c}$.La Jolla Bioengineering Institute, 505 Coast Boulevard South Suite 406, La Jolla, CA, 92037 USA

\begin{abstract}
The synthesis and physico-chemical properties of novel compounds obtained by conjugation of amodiaquine with moieties containing either furoxan or nitrooxy NO-donor substructures are described. The synthesised compounds were tested in vitro against both the chloroquine sensitive , D10 and the chloroquine resistant, W-2 strains of Plasmodium falciparum (P. falciparum). Most of the compounds showed an antiplasmodial activity comparable to that of the parent drug. By comparing the activities of simple related structures devoid of the ability to release NO, it appears that the contribution of $\mathrm{NO}$ to the antiplasmodial action in vitro is marginal. All the compounds were able to relax rat aorta strips with a NO-dependent mechanism, thus showing their capacity to release NO in the vessels. A preliminary in vivo study using Plasmodium berghei ANKA-infected mice showed a trend for prolonged survival of mice with cerebral malaria treated with compound
\end{abstract}

\footnotetext{
${ }^{\dagger}$ Authors contributed equally to this work

* Corresponding author. Tel.: +39 011 6707670; fax: +39 011 6707286. E-mail address: alberto.gasco@unito.it

(A.Gasco).
} 
40, which is potent and fast amodiaquine-derived NO donor, when compared with amodiaquine alone or with compound 31, a milder NO-donor. The two compounds showed in vivo antiplasmodial activity similar to that of amodiaquine.

Keywords: Amodiaquine; Cerebral Malaria; Nitric Oxide; Furoxans; Nitrooxy Derivatives

\section{Introduction}

Malaria is one of the most important causes of parasitic infection and death in the world. A WHO report estimates in 189-327 millions the cases of malaria and in about 1 million the associated deaths, the major part of them occurring in children living in sub-Saharan Africa [1]. There is an increasing need both of new antimalarial drugs and of improvements of those already in use, in particular of agents active against the infection due to Plasmodium falciparum, which is the main agent of severe malaria.

Nitric oxide (NO) is a physiological messenger with multiple actions. In the cardiovascular system it is involved in maintaining the micro- and macro-vascular homeostasis [2]. In particular, it induces vasodilation and inhibits platelet aggregation through a cyclic GMP (cGMP) dependent mechanism and it modulates the expression of the cell-adhesion molecules (CAMs) on endothelial cells. In the central nervous system, it plays complex roles in learning, memory formation and neurotransmitters release, while in the peripheral nervous system behaves as a neurotransmitter at the ends of nonadrenergic, non-cholinergic nerves controlling a number of gastrointestinal, respiratory and genitourinary functions [3]. In the innate immune system NO is one of the final effector molecules against pathogens of different origin. It regulates other immunological functions, as well, including T- and B-cell proliferation, leukocytes rolling and cytokines production [4]. Finally, NO seems to play an important role in the pathogenesis of $P$ falciparum malaria both as antiplasmodial agent and regulator of the immune response to the parasite. This suggested the hypothesis that derivatives of 
NO could be effective antimalarial agents [5]. Indeed, it was found that some NO-donors display in vitro toxic action against $P$. falciparum [6-8].

Severe falciparum malaria, including cerebral malaria $(\mathrm{CM})$, is associated with tissue ischemia related to cytoadherence of parasitized erythrocytes to microvascular endothelium. CM has been reported to be associated to low NO bioavailability in the vasculature $[9,10]$. This is due to both an increased scavenging of NO in the blood, caused by the high concentration of free oxyhaemoglobin $\left(\mathrm{HbO}^{2+}\right)$ from the haemolysis of parasitized red blood cells and to hypoargininemia. Administration of exogenous $\mathrm{NO}$ to the murine model of $\mathrm{CM}$ induced by P.berghei ANKA $(\mathrm{PbA})$ restored signalling in the brain, decreased proinflammatory biomarkers in the blood, and markedly reduced vascular leak and petechial hemorrhages in the brain [10a]. Moreover, a significant improvement of $\mathrm{CM}$ has been observed in patients after infusion of 1-arginine demonstrating that the NO pathway can be targeted for adjunctive treatment in falciparum malaria [10b]. Amodiaquine (AQ, Chart 1 ) is an established antimalarial drug recently reintroduced in the World Health Organisation Model List of Essential Medicines [11, 12].

As development of our previous work aimed at designing new NO-donor multifunctional drugs [13], we now report a study concerning the synthesis, the dissociation constants and the in vitro anti P. falciparum activity of new NO-donor amodiaquine derivatives (NO-AQ) containing either furoxan (1,2,5-oxadiazole 2-oxide) or nitrooxy $\left(-\mathrm{ONO}_{2}\right) \mathrm{NO}$-donor substructures. The capacity of NO-AQ of relaxing rat aorta strips with a NO-dependent mechanism, and in vivo preliminary data which seem to confirm their potential utility in the treatment of CM, are also discussed.

\section{Insert Chart 1}

\section{Results and discussion}

\subsection{Chemistry}


Derivatives $3,4,7, \mathbf{1 2}-15$, bearing nitrooxy functionalities and a primary or a secondary amino group, used for building the final nitrooxy substituted compounds, were synthesised following the pathways described in Scheme 1. Compounds 3 and $\mathbf{4}$ were synthesised by nitration with fuming nitric acid of the related commercially available amino alcohols $\mathbf{1}$ and $\mathbf{2}$. For the synthesis of 6(ethylamino)hexan-1-ol (6) the commercially available 6-chlorohexanol (5) was treated with ethylamine and then with $\mathrm{HCl}$ to give $\mathbf{5 a} \cdot \mathrm{HCl}$. The hydrochloride was converted into the corresponding free base by ion-exchange chromatography on cationic resin (Amberlite IRA-400). This base was transformed into $\mathbf{7} \cdot \mathrm{HNO}_{3}$ by treatment with fuming nitric acid in $34 \%$ overall yield. For the synthesis of piperidino- and piperazino-based nitrooxy derivatives, the commercially available piperidino or piperazino alcohols 8-11 were nitrated following the usual procedure to afford compounds 12-15 in 60-67\% yields.

\section{Insert Scheme 1}

The synthesis of 6-(ethylamino)hexane-1,1-diyl dinitrate (26) was achieved through the route depicted in Scheme 2. The commercially available hex-5-en-1-ol (16) was converted into the corresponding phtalimido derivative $\mathbf{1 7}$, by reaction of the intermediate methansulphonate $\mathbf{1 6 a}$ with potassium phtalimide. Double bond oxidation with $\mathrm{KMnO}_{4}$ in acetone/water afforded the diol $\mathbf{1 8}$, which was then transformed into the dioxolane 19 with acetone and catalytic pyridinium $p$ toluensulfonate (PPTS). Cleavage of the phtalimide moiety by refluxing with hydrazine hydrate in THF afforded the amine 20. The Fukuyama procedure [14] was used in order to obtain the monoalkylated amine 23. 2-nitro-benzenesulphonamide derivative 21, resulting from reaction of $\mathbf{2 0}$ with 2-nitrobenzenesulfonyl chloride in the presence of triethylamine, was alkylated with excess ethyl iodide in basic medium to afford 22. Treatment of this product with tiophenol and $\mathrm{KOH}$ under nitrogen atmosphere gave the expected secondary amine $\mathbf{2 3}$. The dioxolane ring of this intermediate was cleaved by treatment with refluxing $80 \% \mathrm{CF}_{3} \mathrm{COOH}$ solution and subsequent conversion of the obtained aminodiol trifluoroacetate $\mathbf{2 4}$ to the corresponding free base by ion-exchange 
chromatography; $\mathbf{2 5}$ was then treated with fuming nitric acid to afford the final double nitrated aminodiol 26 as $\mathrm{HNO}_{3}$ salt.

\section{Insert Scheme 2}

The synthesis of final AQ derivatives 28-31, 32-35 bearing nitrooxy groups (Scheme 3) was carried out by nucleophilic displacement of benzylic chlorine atom present on versatile intermediate 27 we have previously described [15], by the appropriate nitrooxy substituted primary and secondary amines. The reaction, was performed in a 1:1 mixture of DMF and $\mathrm{CH}_{3} \mathrm{CN}$, in the presence of triethylamine. Compounds 28-30, 32-35 were converted to the corresponding hydrochlorides by treatment of their methanolic solution with $\mathrm{HCl}$-saturated $\mathrm{Et}_{2} \mathrm{O}$, while compound $\mathbf{3 1}$ was kept as the free base.

Insert Scheme 3

The final AQ derivatives $\mathbf{3 7}, \mathbf{4 0}$ bearing furoxan moieties were synthesised starting from 27 (Scheme 4). To obtain the phenylfuroxanyl substituted compound $\mathbf{3 7}$ the chloromethyl substituted intermediate 27 was transformed into hydroxyamodiaquine 36 by treatment with 2-ethylamino ethanol in acetonitrile. This last compound was treated with 3-phenyl-4-benzenesulfonyl furoxan and $50 \%(\mathrm{w} / \mathrm{w}) \mathrm{NaOH}$, under nitrogen atmosphere in distilled THF/DMF mixture, to give the desired product. Owing to extensive decomposition of the reaction mixture, it was impossible to obtain 40 in the same way. This product was obtained by reacting 27 with $N$-ethyl-2-((3phenylsulfonyl)furoxan-4-yl)oxy)ethanamine 39 that, in its turn, was obtained by $\mathrm{NaOH}$-mediated reaction of 2-(ethylamino)ethanol with bis-benzenesulfonyl furoxan $\mathbf{3 8}$. The proposed structure of 39 was confirmed by its ${ }^{13} \mathrm{C}-\mathrm{NMR}$ spectrum, which is typical of a 4-alkoxy-3-phenylsulfonyl substituted furoxan [16]. 


\subsection{Dissociation constants determination}

Potentiometric titrations of the final amodiaquine derivatives were performed with a Sirius $\mathrm{GLp} K_{\mathrm{a}}$ automated potentiometric system. The titrations were carried out in water using methanol in different ratios as co-solvent; the aqueous $\mathrm{p} K_{\mathrm{a}} \mathrm{s}$ were determined by extrapolation to $0 \%$ methanol according to Yasuda-Shedlovsky procedure (see experimental). The $p K_{\mathrm{a}}$ values are listed in Table 1 . Using AQ as reference compound ( $p K_{\mathrm{a} 1}=8.47$, lateral chain nitrogen; $p K_{\mathrm{a} 2}=7.42$, 4-aminoquinoline

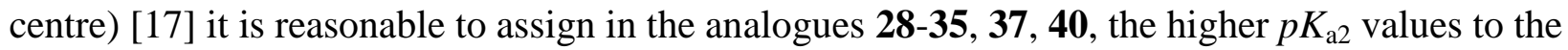
basic centre of the lateral chains, and the lower $p K_{\mathrm{a} 1}$ values to the 4-aminoquinoline moiety. In the case of the piperazino substituted compounds $34,35, p K_{\mathrm{a} 3}$ values could be related with aminoquinoline scaffold, while $p K_{\mathrm{a} 1}$ and $p K_{\mathrm{a} 2}$ values with the piperazine substructure. From the data of the Table 1, it is immediately deducible that at $\mathrm{pH}$ (5.2) of parasite food vacuole all the products exist in the dicationic form in equilibrium with the monocationic one, while at physiological $\mathrm{pH}$ (7.4) as complex equilibrium between neutral, monocationic and dicationic species.

\subsection{Biological activities}

\subsubsection{In vitro antimalarial activity against (CQS) D10 and (CQR) W-2 strains of $P$. falciparum}

All the final products were screened in vitro against the chloroquine sensitive (CQ-S) D10 and the chloroquine resistant (CQ-R) W-2 strains of $P$. falciparum. The results, expressed as 50\% inhibitory concentrations $\left(\mathrm{IC}_{50}\right)$ are shown in Table 2 . All tested compounds including the NO-AQ 
derivatives retained significant activity against both strains in the low $\mathrm{nM}$ range. The most active compounds are the piperidine and the piperazine derivatives $\mathbf{3 2}$ and $\mathbf{3 5}$, which display an antiplasmodial potency near to that of the lead. Also the activity of this class against the W-2, CQ-R strain is similar to that of AQ, within the limits of the experimental errors, with the only exception of the furoxan and piperazine compounds $\mathbf{4 0}$ and $\mathbf{3 4}$, respectively, which show signs of cross resistance with $\mathrm{CQ}$.

No activity in the nM range was observed for the simple nitric acid esters $\mathbf{3}, \mathbf{7}, \mathbf{1 2}-\mathbf{1 5}$, used to prepare the nitrooxysubstituted NO-AQ, as well as for the two simple furoxans $\mathbf{A}, \mathbf{B}$ (Table 2) structurally similar to the furoxan moieties present in $\mathbf{3 7}$ and $\mathbf{4 0}$ respectively. These results indicate that the contribution of NO to the antiplasmodial properties of NO-AQ is, if any, secondary to that of the lead structure.

\subsubsection{Vasodilator activity}

All the NO-AQ products described in this work were able to relax rat aorta strips precontracted with phenylephrine. The vasodilator potencies, expressed as $\mathrm{EC}_{50}$, are reported in Table 2. Analysis of the data indicates that the most potent compounds appear to be the dinitrooxy- and the furoxansubstituted products $\mathbf{3 5}$ and $\mathbf{4 0}$, respectively, which display their action in the nM range. The remaining products show $\mathrm{EC}_{50}$ values all included in a very narrow range $0.10 \div 1.2 \mu \mathrm{M}$. When the experiments were repeated in the presence of $1 \mu \mathrm{M}$ ODQ $(1 H$-[1,2,4]oxadiazolo[4,3-a]quinoxalin1-one), a well known inhibitor of the soluble guanylate cyclase (sGC), a decrease in the potencies was observed. These results indicate the ability of these products to release NO in the vessels with consequent NO-dependent vasodilation, thus suggesting their potential use as adjunct therapy for CM. 


\subsubsection{Ability of compounds 31 and 40 to improve survival of mice from late-stage cerebral malaria (CM).}

To test this hypothesis, preliminary in vivo experiments were conducted with compounds $\mathbf{3 1}$ and $\mathbf{4 0}$ using the murine model of $\mathrm{CM}$ caused by P. berghei ANKA $(\mathrm{PbA})$. Infected mice with late stage CM (i.e., presenting neurological signs, hypothermia and low motor scores) treated with compound 40 (1.4mg per mouse) daily for 5 days presented a trend for delayed mortality and increased survival as compared to AQ (1 $\mathrm{mg}$ per mouse) alone. Compound $\mathbf{4 0}$ slightly improved the survival to $23 \%$ and had an efficacy in parasite clearance ( $76 \%$ reduction of parasitaemia in 24 hours) similar to that of AQ ( $8 \%$ survival, $72 \%$ of parasite clearance in 24 hours) (Figures 1A and 1C). The same trend was not observed with compound 31 (1.15mg per mouse), a milder NO donor (Figures 1B and 1D). Total parasite clearance with both compounds and AQ was achieved after 72 hours and three doses of treatment in mice that survived and no recrudescence was observed after a 5-day treatment regimen (Figure 1C and 1D).

\section{Conclusions}

We have developed a new series of NO-AQ derivatives which are able to retain a high degree of activity in vitro against both CQ-S and CQ-R strains of $P$. falciparum. At least in vitro, the contribution of NO to the antiplasmodial properties of these products seems to be secondary to that of the lead. All the compounds are able, in different degree, to dilate pre-contracted rat aorta strips with a NO-dependent mechanism, and consequently they could be capable to help restoring the vascular homeostasis which is deeply compromised in CM. Indeed, low NO bioavailability plays a role in the pathogenesis of murine CM [10], which is associated with cerebral microcirculatory dysfunction and vasoconstriction [18]. Treatment with an NO donor, 1-[N-(3-Aminopropyl)-N-(3ammoniopropyl)]diazen-1-ium-1,2-diolate (DPTA-NO) largely prevents the neurological syndrome 
and this is associated with improved cerebral vascular responses [19]. We asked whether a hybrid compound endowed with antimalarial and NO activities could improve survival in mice with late stage CM, in comparison with its lead compound presenting antimalarial activity only. Our preliminary results with compounds $\mathbf{4 0}$ and $\mathbf{3 1}$ in the murine model of CM by P. berghei ANKA indeed showed a trend for increased survival of the animals treated with compound 40, which is a potent and fast NO-donor. It is remarkable that survival rates were increased three-fold, especially considering that mice left untreated at late stage of CM die in a few hours, and AQ by itself was highly ineffective at this stage. Earlier treatment and shorter intervals for drug administration may help to further improve the efficacy. The same trend for increased survival was not observed with compound 31, a milder NO-donor. Further in vivo studies are in progress to disclose the interesting potentialities of these products, and of other NO-donor antimalarial drugs, in the treatment of CM.

\section{Experimental}

\subsection{Instrumentation and chemicals}

Melting points were determined with a capillary apparatus Büchi B-540 or Büchi B-530 (uncorrected). Melting point with decomposition were determined after introduction of the sample at a temperature $10{ }^{\circ} \mathrm{C}$ lower than the melting point. A heating rate of $2{ }^{\circ} \mathrm{C} \min ^{-1}$ was used. ${ }^{1} \mathrm{H}$ and ${ }^{13} \mathrm{C}$ NMR spectra were obtained on a Bruker Avance 300, at 300 and $75 \mathrm{MHz}$ respectively or Bruker AC-200, at 200 and $50 \mathrm{MHz}$ respectively; $\delta$ in ppm rel. to $\mathrm{SiMe}_{4}$ as the internal standard; coupling constants $J$ in Hz. ${ }^{13} \mathrm{C}$ NMR spectra were fully decoupled. The following abbreviations are used: s: singlet, d: doublet, dd: doublet doublet, t: triplet, qt: quartet, m: multiplet, br: broad, Fx: furoxan, Q: quinoline ring, AQ: amodiaquine. Mass spectra were recorded on a Finnigan-Mat TSQ700. Flash chromatography (FC) was performed on BDH silica gel (particle size 40-63 $\mu \mathrm{m}$ ). When not otherwise specified, anhydrous magnesium sulphate $\left(\mathrm{MgSO}_{4}\right)$ was used as the drying agent of organic phases. Analysis $(\mathrm{C}, \mathrm{H}, \mathrm{N})$ of the target compounds was performed by Service de 
Microanalyse, Université de Genève, Genève $(\mathrm{CH})$ and REDOX (Monza) and the results were within $\pm 0.4 \%$ of the theoretical. 3-phenyl-4-benzenesulfonyl furoxan [20], 3 [21], 27 [15], 38 [22], A, B [23], were synthesised according to reported methods.

\subsection{Chemistry}

\subsubsection{6-(ethylamino)hexan-1-ol (6)}

6-chlorohexan-1-ol (5) (3.5 g; $26 \mathrm{mmol})$ was added to $70 \mathrm{ml}$ of $\mathrm{EtNH}_{2} 70 \%$ solution in water. The solution was kept under stirring at room temperature for $48 \mathrm{~h}$. The solution was then evaporated under reduced pressure and the residue was taken up with $1 \mathrm{~N} \mathrm{HCl}$ and washed three times with $\mathrm{CH}_{2} \mathrm{Cl}_{2}$; the aqueous phase was filtered and dried under reduced pressure. The residue was eluted through an ion-exchange column over Amberlite IRA-400 resin to afford $1.76 \mathrm{~g}$ of the title product as a colourless oil $\left(52 \%\right.$ free base). ${ }^{1} \mathrm{H}-\mathrm{NMR}\left(\mathrm{CD}_{3} \mathrm{OD}\right): \delta, 3.58-3.53\left(\mathrm{~m}, 2 \mathrm{H}, \mathrm{CH}_{2} \mathrm{O}\right) ; 3.02-2.89$ $\left(\mathrm{m}, 4 \mathrm{H}, \mathrm{CH}_{2} \mathrm{NHCH}_{2}\right) ; 1.68-1.41\left(\mathrm{~m}, 6 \mathrm{H}, 3 \mathrm{CH}_{2}\right) ; 1.28\left(\mathrm{t}, J=7.2 \mathrm{~Hz}, 3 \mathrm{H}, \mathrm{CH}_{3}\right) .{ }^{13} \mathrm{C}-\mathrm{NMR}$ $\left(\mathrm{CD}_{3} \mathrm{OD}\right): \delta, 61.3 ; .47 .4 ; 42.8 ; 32.0 ; 26.5 ; 26.2 ; 25.2 ; 10.8 . \mathrm{MS} \mathrm{CI}$ (isobutane) $(\mathrm{m} / \mathrm{z}): 146\left[\mathrm{MH}^{+}\right]$.

\subsubsection{N-ethyl-6-(nitrooxy)hexan-1-ammonium nitrate (7)}

To $10 \mathrm{ml}$ of fuming nitric acid at $-15^{\circ} \mathrm{C}, 0.55 \mathrm{~g}(3.8 \mathrm{mmol})$ of 6 were added dropwise. The mixture was allowed to warm at room temperature and was kept under stirring for $24 \mathrm{~h}$. The solution was then evaporated under reduced pressure and the residue was dropped in $100 \mathrm{ml}$ of anhydrous $\mathrm{Et}_{2} \mathrm{O}$ at $-15^{\circ} \mathrm{C}$. After $2 \mathrm{~h}$ at $0{ }^{\circ} \mathrm{C}$ the solvent was decanted off and the semisolid residue was triturated several times with fresh diethyl ether and was used without further purification. The product was characterized as free base which was obtained by extraction of a slurry of the semisolid with $\mathrm{Na}_{2} \mathrm{CO}_{3}$, with EtOAc. The organic phase was then washed with brine, dried over $\mathrm{Na}_{2} \mathrm{SO}_{4}$ and the solvent was evaporated under reduced pressure. The residue was purified by flash chromatography on silica gel eluting with DCM/MeOH $5 \%$ to afford $0.62 \mathrm{~g}$ of the desired product as a colorless oil $(65 \%) .{ }^{1} \mathrm{H}-\mathrm{NMR}\left(\mathrm{DMSO}-d_{6}\right): \delta, 4.51\left(\mathrm{t}, J=6.1 \mathrm{~Hz}, 2 \mathrm{H}, \mathrm{CH}_{2} \mathrm{ONO}_{2}\right) ; .2 .55-2.43(\mathrm{~m}, 4 \mathrm{H}$, 
$\left.\mathrm{CH}_{2} \mathrm{NCH}_{2}\right) ; 1.70-1.61\left(\mathrm{~m}, 2 \mathrm{H}, \mathrm{CH}_{2}\right) ; 1.44-1.31\left(\mathrm{~m}, 6 \mathrm{H}, 3 \mathrm{CH}_{2}\right) ; 0.99\left(\mathrm{t}, J=7.1 \mathrm{~Hz}, 3 \mathrm{H}, \mathrm{CH}_{3}\right)$.

${ }^{13} \mathrm{C}-\mathrm{NMR}\left(\mathrm{DMSO}-d_{6}\right): \delta, 74.2 ; 49.2 ; 43.8 ; 29.3 ; 26.7 ; 26.4 ; 25.4 ; 15.1$.

\subsubsection{General procedure for the synthesis of derivatives 4, 12-15.}

The appropriate alcohol was added dropwise to $15 \mathrm{ml}$ of fuming nitric acid at $-15^{\circ} \mathrm{C}$. The mixture was allowed to warm at room temperature and was kept under stirring for $24 \mathrm{~h}$. The solution was then evaporated under reduced pressure and the residue was dropped in $100 \mathrm{ml}$ of anhydrous $\mathrm{Et}_{2} \mathrm{O}$ at $-15{ }^{\circ} \mathrm{C}$. After $2 \mathrm{~h}$ at $0{ }^{\circ} \mathrm{C}$ the solvent was decanted off and the semisolid residue was triturated several times with fresh diethyl ether to obtain an off-white solid (60-93\% yields).

\subsubsection{1. $\quad \mathrm{N}$-ethyl-3-(nitrooxy)propan-1-ammonium nitrate (4).}

${ }^{1} \mathrm{H}-\mathrm{NMR}$ (DMSO-d $d_{6}$ ): $\delta, 8.45$ (s, 2H, exch. sign.); 4.60 (t, $J=4.5 \mathrm{~Hz}, 2 \mathrm{H}, \mathrm{CH}_{2} \mathrm{ONO}_{2}$ ); 2.99 (m, $2 \mathrm{H}$, $\mathrm{CH}_{2} \mathrm{CH}_{2} \mathrm{CH}_{2}$ ); 1.17 (t, $J=5.5 \mathrm{~Hz}, 3 \mathrm{H}, \mathrm{CH}_{3}$ ). ${ }^{13} \mathrm{C}-\mathrm{NMR}$ (DMSO-d $): \delta, 70.8 ; 43.2 ; 42.2 ; 23.2 ; 11.0$.

\subsubsection{2. $\quad$ 4-[(nitrooxy)methyl]piperidinium nitrate (12).}

${ }^{1} \mathrm{H}-\mathrm{NMR}\left(\mathrm{DMSO}-d_{6}\right): \delta, 8.68\left(\mathrm{br} \mathrm{s}, 1 \mathrm{H}, \mathrm{NH}^{+}\right) ; 8.34\left(\mathrm{br} \mathrm{s}, 1 \mathrm{H}, \mathrm{NH}^{+}\right) ; 4.45(\mathrm{~d}, J=6.4 \mathrm{~Hz}, 2 \mathrm{H}$, $\left.\mathrm{CH}_{2} \mathrm{ONO}_{2}\right) ; 3.34-3.30$ (m, 2H, $\mathrm{CH}_{2}$-piperidine); 2.98 - 2.86 (m, 2H, $\mathrm{CH}_{2}$-piperidine); 2.10 - 2.04 (m, 1H, CH-piperidine); 1.87 - 1.82 (m, 2H, $\mathrm{CH}_{2}$-piperidine); $1.51-1.38$ (m, 2H, $\mathrm{CH}_{2}$-piperidine). ${ }^{13} \mathrm{C}-\mathrm{NMR}\left(\mathrm{DMSO}-d_{6}\right): \delta, 76.6 ; 42.8 ; 31.4 ; 25.1$. Spectral data were consistent with the reported ones[22].

\subsubsection{4-[2-(nitrooxy)ethyl]piperidinium nitrate (13).}

${ }^{1} \mathrm{H}-\mathrm{NMR}\left(\mathrm{CD}_{3} \mathrm{OD}\right): \delta, 4.45\left(\mathrm{t}, J=6.3 \mathrm{~Hz}, 2 \mathrm{H}, \mathrm{CH}_{2} \mathrm{ONO}_{2}\right) ; 3.30-3.25$ (m, 2H, $\mathrm{CH}_{2}$-piperidine) $2.91-2.83\left(\mathrm{~m}, 2 \mathrm{H}, \mathrm{CH}_{2}\right.$-piperidine); $1.88-1.83$ (m, 2H, $\mathrm{CH}_{2}$-piperidine); $1.64-1.58$ (m, 3H, $\left.\mathrm{CH}_{2}, \mathrm{CH}\right) ; 1.37$ - 1.30 (m, 2H, $\mathrm{CH}_{2}$-piperidine). ${ }^{13} \mathrm{C}-\mathrm{NMR}\left(\mathrm{CD}_{3} \mathrm{OD}\right): \delta, 71.5 ; 55.2 ; 53.3 ; 44.5$; $33.0 ; 31.3 ; 29.0$. Spectral data were consistent with the reported ones[24]. 


\subsubsection{1-[2-(nitrooxy)ethyl]piperazin-4-ium nitrate (14).}

${ }^{1} \mathrm{H}-\mathrm{NMR}\left(\mathrm{DMSO}-d_{6}\right): \delta, 9.09\left(\mathrm{br} \mathrm{s}, 2 \mathrm{H}, 2 \mathrm{NH}^{+}\right) ; 4.87\left(\mathrm{t}, J=4.6 \mathrm{~Hz}, 2 \mathrm{H}, \mathrm{CH}_{2} \mathrm{ONO}_{2}\right) ; 3.62(\mathrm{~m}, 2 \mathrm{H}$, $\mathrm{CH}_{2}$-lateral chain); 3.41 - 3.32 (m, 8H, $4 \mathrm{CH}_{2}$-piperazine). ${ }^{13} \mathrm{C}-\mathrm{NMR}$ (DMSO- $\left.d_{6}\right): \delta, 67.3 ; 52.6$; 48.6; 40.4. Spectral data were consistent with the reported ones [25].

\subsubsection{1-[3-(nitrooxy)propyl]piperazin-4-ium nitrate (15).}

${ }^{1} \mathrm{H}-\mathrm{NMR}\left(\mathrm{DMSO}-d_{6}\right): \delta, 9.10\left(\mathrm{br} \mathrm{s}, 2 \mathrm{H}, 2 \mathrm{NH}^{+}\right) ; 4.61\left(\mathrm{t}, J=6.0 \mathrm{~Hz}, 2 \mathrm{H}, \mathrm{CH}_{2} \mathrm{ONO}_{2}\right) ; 4.0-3.28(\mathrm{~m}$, $\left.10 \mathrm{H}, 5 \mathrm{CH}_{2}\right) ; 2.14-2.05$ (m, $2 \mathrm{H}, \mathrm{CCH}_{2} \mathrm{C}$-lateral chain). ${ }^{13} \mathrm{C}-\mathrm{NMR}$ (DMSO- $\left.d_{6}\right): \delta, 70.8 ; 52.7 ; 48.5$; 40.6; 21.4. Spectral data were consistent with the reported ones [25].

\subsubsection{2-hex-5-enyl-1H-isoindole-1,3(2H)-dione (17).}

5-hexen-1-ol 16 (10 g, $10 \mathrm{mmol}$ ) was converted to the corresponding methanesulfonate according to a reported procedure [26]. The crude product was then suspended in $\mathrm{CH}_{3} \mathrm{CN}$ with potassium phtalimide (1.5 eq) and a catalytic amount of potassium iodide. The mixture was refluxed for $72 \mathrm{~h}$, then cooled and filtered on a sintered-glass funnel. The filtrate was purified by flash chromatography eluting with PE/EtOAc $10 \%$ to afford the desired product as a white solid (20 g, $86 \%)$. Spectral data were consistent with the reported ones [27]. ${ }^{1} \mathrm{H}-\mathrm{NMR}\left(\mathrm{CDCl}_{3}\right): \delta, 7.86-7.80$ (m, 2H arom); $7.64-7.68(\mathrm{~m}, 2 \mathrm{H}$ arom $) ; 5.85-5.71(\mathrm{~m}, 1 \mathrm{H}, \mathrm{CH}=) ; 5,04-4.92\left(\mathrm{~m}, 2 \mathrm{H}, \mathrm{CH}_{2}=\right) ; 3.69$ $\left(\mathrm{t}, 2 \mathrm{H}, J=7.2 \mathrm{~Hz}, \mathrm{CH}_{2} \mathrm{~N}\right) ; 2.13-2.05\left(\mathrm{~m}, 2 \mathrm{H}, \mathrm{CH}_{2} \mathrm{CH}\right) ; 1.72-1.67\left(\mathrm{~m}, 2 \mathrm{H}, \mathrm{CH}_{2}\right) ; 1.50$ - $1.40(\mathrm{~m}$, $\left.2 \mathrm{H}, \mathrm{CH}_{2}\right) .{ }^{13} \mathrm{C}-\mathrm{NMR}\left(\mathrm{CDCl}_{3}\right): \delta, 168.4 ; 138.2 ; 133.8 ; 132.1 ; 123.1 ; 114.9 ; 37.8 ; 33.2 ; 28.0 ; 26.1$; 21.0. MS CI (isobutane) (m/z): $230\left[\mathrm{MH}^{+}\right]$. M.p. (n-hexane): $52.5^{\circ} \mathrm{C}$.

\subsubsection{2-(5,6-dihydroxyhexyl)-1H-isoindole-1,3(2H)-dione (18).}

To a solution of $5 \mathrm{~g}$ of $\mathbf{1 7}(22 \mathrm{mmol})$ in $200 \mathrm{ml}$ of acetone cooled in an ice bath, a solution of $\mathrm{KMnO}_{4}$ in $200 \mathrm{ml}$ of water was added dropwise. After the addition was over the mixture was 
allowed to raise to room temperature and kept under stirring for further $3 \mathrm{~h}$; the brownish solid was filtered off on a sintered glass funnel and the filtrate was concentrated under reduced pressure. The residue was taken up with $100 \mathrm{ml}$ of water and extracted with EtOAc $(6 \times 50 \mathrm{ml})$. The organic extracts were washed with brine $(1 \times 100 \mathrm{ml})$, dried and the solvent was evaporated under reduced pressure. The crude product was purified by flash chromatography on silica gel eluting with $\mathrm{CH}_{2} \mathrm{Cl}_{2} / \mathrm{CH}_{3} \mathrm{OH} 5 \%$ to afford $3.16 \mathrm{~g}(56 \%)$ of the desired product as white solid. Spectral data were consistent with the reported ones [28]. ${ }^{1} \mathrm{H}-\mathrm{NMR}\left(\mathrm{CD}_{3} \mathrm{OD}\right): \delta, 7.85$ - 7.76 (m, 4Harom); 3.70 - 3.30 (m, 5H, $\left.\mathrm{CH}_{2} \mathrm{~N}, \mathrm{CHOH}, \mathrm{CH}_{2} \mathrm{OH}\right) ; 1.74-1.27$ (m, 6H, $\left.\mathrm{CH}_{2} \mathrm{CH}_{2} \mathrm{CH}_{2}\right) .{ }^{13} \mathrm{C}-\mathrm{NMR}\left(\mathrm{CD}_{3} \mathrm{OD}\right): \delta, 169.8$; $135.3 ; 133.4 ; 124.0 ; 73.0 ; 67.3 ; 38.8 ; 33.9 ; 29.6 ; 24.0 ; 23.3$.

MS (CI) (isobutane) (m/z): $264\left[\mathrm{MH}^{+}\right]$. M.p. (iPr $\left.2 \mathrm{O} / \mathrm{iPrOH}\right): 65^{\circ} \mathrm{C}$.

\subsubsection{2-[4-(2,2-dimethyl-1,3-dioxolan-4-yl)butyl]-1H-isoindole-1,3(2H)-dione (19).}

To a solution of $\mathbf{1 8}(3.16 \mathrm{~g} ; 12 \mathrm{mmol})$ in $200 \mathrm{ml}$ of acetone, pyridinium p-toluenesulfonate ( $0.3 \mathrm{~g} ; 1$ mmol) was added. The mixture was stirred at room temperature for $18 \mathrm{~h}$, then evaporated under reduced pressure and purified by flash chromatography on silica gel to afford $3.03 \mathrm{~g} \mathrm{(80 \% )} \mathrm{of} \mathrm{title}$ product as a white solid. Spectral data were consistent with the reported ones [28]. ${ }^{1} \mathrm{H}-\mathrm{NMR}$ $\left(\mathrm{CDCl}_{3}\right): \delta, 7.86-7.80(\mathrm{~m}, 2 \mathrm{H}$ arom); $7.74-7.68(\mathrm{~m}, 2 \mathrm{H}$ arom); $4.11-4.00(\mathrm{~m}, 2 \mathrm{H}, 2 \mathrm{CHO}) ; 3.70$ $\left(\mathrm{t}, J=7.2 \mathrm{~Hz}, 2 \mathrm{H}, \mathrm{CH}_{2} \mathrm{~N}\right) ; 3.54-3.44(\mathrm{~m}, 1 \mathrm{H}, \mathrm{CHO}) ; 1.77-1.46\left(\mathrm{~m}, 6 \mathrm{H}, 3 \mathrm{CH}_{2}\right) ; 1.40(\mathrm{~s}, 3 \mathrm{H}$, $\left.\mathrm{CH}_{3}\right) ; 1.34\left(\mathrm{~s}, 3 \mathrm{H}, \mathrm{CH}_{3}\right) .{ }^{13} \mathrm{C}-\mathrm{NMR}\left(\mathrm{CDCl}_{3}\right): \delta, 168.4 ; 165.7 ; 133.9 ; 132.1 ; 123.2 ; 108.72 ; 75.8 ;$ 71.9; 69.4; 37.8; 33.1; 28.6; 26.9; 25.7; 23.1. MS CI (isobutane) (m/z): $304\left[\mathrm{MH}^{+}\right]$. M.p. (nhexane): $121{ }^{\circ} \mathrm{C}$.

\subsubsection{4-(2,2-dimethyl-1,3-dioxolan-4-yl)butan-1-amine (20).}

To a stirred solution of $\mathbf{1 9}(3 \mathrm{~g} ; 10 \mathrm{mmol})$ in $100 \mathrm{ml}$ of distilled THF, hydrazine monohydrate (3.9 $\mathrm{ml} ; 8$ eq.) was added and the mixture was stirred under reflux for $24 \mathrm{~h}$. After cooling the mixture was filtered on a sintered-glass funnel and the filtrate was evaporated under reduced pressure. The 
residue was purified by flash chromatography on silica gel eluting with DCM/MeOH 5\%, $\mathrm{DCM} / \mathrm{MeOH} 10 \% \mathrm{NH}_{3}$ soln $1 \%$ affording the desired product as a colourless oil $(0.9 \mathrm{~g} 52 \%)$.

Spectral data were consistent with the reported ones [29]. ${ }^{1} \mathrm{H}-\mathrm{NMR}\left(\mathrm{CDCl}_{3}\right): \delta, 4.13-4.01(\mathrm{~m}, 2 \mathrm{H}$, $\left.\mathrm{CH}_{2} \mathrm{O}\right) ; 3.54-3.47(\mathrm{~m}, 1 \mathrm{H}, \mathrm{CH}) ; 2,7\left(\mathrm{t}, 2 \mathrm{H}, \mathrm{J}=6.9 \mathrm{~Hz}, \mathrm{CH}_{2} \mathrm{~N}\right) ; 1.95\left(\mathrm{~s}, 3 \mathrm{H}, \mathrm{CH}_{2}, \mathrm{CH}\right) ; 1.40$ (s, 3H, $\left.\mathrm{CH}_{3}\right) ; 1.35$ (s, $\left.3 \mathrm{H}, \mathrm{CH}_{3}\right) .{ }^{13} \mathrm{C}-\mathrm{NMR}\left(\mathrm{CDCl}_{3}\right): \delta, 108.6 ; 77.2 ; 75.9 ; 69.4 ; 41.8 ; 33.3 ; 26.9 ; 25.7 ; 23.2$. MS CI (isobutane) (m/z): $174\left[\mathrm{MH}^{+}\right]$.

\subsubsection{N-[4-(2,2-dimethyl-1,3-dioxolan-4-yl)butyl]-2-nitrobenzenesulfonamide (21).}

To a solution of $0.9 \mathrm{~g}(5 \mathrm{mmol})$ of $\mathbf{2 0}$ and $\mathrm{Et}_{3} \mathrm{~N}(1.1 \mathrm{eq})$ in $20 \mathrm{ml}$ of DCM cooled in an ice bath, 2nitrobenzensulfonilchloride $(1 \mathrm{eq})$ was added portionwise. The mixture was stirred at RT for 30 min, taken up with DCM and washed with $20 \mathrm{ml}$ of $1 \mathrm{~N} \mathrm{HCl}$; the aqueous phase was extracted with $\operatorname{DCM}(2 \times 10 \mathrm{ml})$ and the organic phase was then washed with water and brine, dried over $\mathrm{Na}_{2} \mathrm{SO}_{4}$, filtered and evaporated under reduced pressure. The residue was purified by flash chromatography on silica gel, eluting with PE/EtOAc $30 \%$ to afford the desire product as a colourless oil (1.55 g, 83\%). ${ }^{1} \mathrm{H}-\mathrm{NMR}\left(\mathrm{CDCl}_{3}\right): \delta, 8.13-8.10$ (m, 1H arom); 7.86 - 7.77 (m, 3H arom); 5.76 - 5.73 (m, $1 \mathrm{H}, \mathrm{CH}) ; 4.14-3.98\left(\mathrm{~m}, 2 \mathrm{H}, \mathrm{CH}_{2} \mathrm{O}\right) ; 3.38-3.44(\mathrm{~m}, 1 \mathrm{H}, \mathrm{NH}) ; 3.13\left(\mathrm{qt}, 2 \mathrm{H}, J=6.3 \mathrm{~Hz}, \mathrm{CH}_{2} \mathrm{~N}\right)$; 1.60 - $1.36\left(\mathrm{~m}, 6 \mathrm{H}, \mathrm{CH}_{2} \mathrm{CH}_{2} \mathrm{CH}_{2}\right) ; 1.32\left(\mathrm{~s}, 3 \mathrm{H}, \mathrm{CH}_{3}\right) ; 1.26\left(\mathrm{~s}, 3 \mathrm{H}, \mathrm{CH}_{3}\right) .{ }^{13} \mathrm{C}-\mathrm{NMR}\left(\mathrm{CDCl}_{3}\right): \delta$, $148.2 ; 135.6 ; 134.2 ; 133.6 ; 133.2 ; 131.1 ; 125.5 ; 108.8 ; 76.0 ; 69.5 ; 43.9 ; 33.2 ; 29.8 ; 27.2 ; 26.0$; 25.5; 23.0; 14.5. MS CI (isobutane) $(\mathrm{m} / \mathrm{z}): 359\left[\mathrm{MH}^{+}\right]$.

\subsection{9. $N$-[4-(2,2-dimethyl-1,3-dioxolan-4-yl)butyl]-N-ethyl-2-nitrobenzenesulfonamide (22).}

To a stirred solution of 21 (1.55 g; $4.3 \mathrm{mmol})$ in $50 \mathrm{ml}$ of DMF, $\mathrm{K}_{2} \mathrm{CO}_{3}(10 \mathrm{eq})$ and EtI (1.5 eq) were added. The solution was stirred at $60{ }^{\circ} \mathrm{C}$ for $10 \mathrm{hrs}$, taken up with $100 \mathrm{ml} \mathrm{of} \mathrm{Et}_{2} \mathrm{O}$ and washed with water $(3 \times 50 \mathrm{ml})$ and brine; the organic phase was dried over $\mathrm{Na}_{2} \mathrm{SO}_{4}$, filtered and dried under reduced pressure. The residue was purified by flash chromatography on silica gel eluting with PE/EtOAc $30 \%$, to afford the desired product as a pale yellow oil $(1.63 \mathrm{~g} 98 \%) .{ }^{1} \mathrm{H}-\mathrm{NMR}\left(\mathrm{CDCl}_{3}\right)$ : 
$\delta, 8.02-7.99(\mathrm{~m}, 1 \mathrm{H}$ arom); $7.70-7.67(\mathrm{~m}, 2 \mathrm{H}$ arom); $7.65-7.60(\mathrm{~m}, 1 \mathrm{H}$, arom $) ; 4.07-3.99(\mathrm{~m}$, $\left.2 \mathrm{H}, \mathrm{CH}_{2} \mathrm{O}\right) ; 3.50-3.46(\mathrm{~m}, 1 \mathrm{H}, \mathrm{CH}) ; 3.40-3.28\left(\mathrm{~m}, 4 \mathrm{H}, \mathrm{NCH}_{2} \mathrm{CH}_{3}, \mathrm{NCH}_{2}\right) ; 1.66-1.29(\mathrm{~m}, 12 \mathrm{H}$, $\left.3 \mathrm{CH}_{2}, \mathrm{CH}_{3} \mathrm{CCH}_{3}\right) ; 1.12\left(\mathrm{t}, J=7.2 \mathrm{~Hz}, 3 \mathrm{H}, \mathrm{CH}_{3} \mathrm{CH}_{2}\right) .{ }^{13} \mathrm{C}-\mathrm{NMR}\left(\mathrm{CDCl}_{3}\right): \delta, 133.8,133.4$, 130.6,127.0, 75.8, 69.3, 46.7, 42.0, 36.5, 33.0, 31.4, 28.3, 26.9, 25.7, 22.8, 13.7. MS CI (isobutane) $(\mathrm{m} / \mathrm{z}): 387\left[\mathrm{MH}^{+}\right]$.

\subsubsection{0. $\mathrm{N}$-[4-(2,2-dimethyl-1,3-dioxolan-4-yl)butyl]-N-ethylamine (23).}

A solution of $1.08 \mathrm{ml}$ (2.5 eq) of thiophenol in $15 \mathrm{ml}$ of $\mathrm{CH}_{3} \mathrm{CN}$ kept under $\mathrm{N}_{2}$ was cooled in an ice bath. To this solution $0.60 \mathrm{~g}$ of $\mathrm{KOH}$ (2.5 eq) dissolved in $2 \mathrm{ml}$ of water were added dropwise. After $10 \mathrm{~min} 1.63 \mathrm{~g}$ of $22(0.004 \mathrm{~mol})$ dissolved in $10 \mathrm{ml}$ of $\mathrm{CH}_{3} \mathrm{CN}$ were added dropwise over a period of $20 \mathrm{~min}$. The mixture was stirred at $50{ }^{\circ} \mathrm{C}$ for $4 \mathrm{~h}$, then it was filtered and the filtrate was evaporated under reduced pressure. The residue was purified by flash chromatography on silica gel, eluting with DCM, DCM/MeOH 5\%, DCM/MeOH $10 \% \mathrm{NH}_{3} 1 \%$ to afford the title product as a colourless oil (0.65 g 77\%). ${ }^{1} \mathrm{H}-\mathrm{NMR}\left(\mathrm{CDCl}_{3}\right): \delta, 4.10-4.01\left(\mathrm{~m}, 2 \mathrm{H}, \mathrm{CH}_{2} \mathrm{O}\right) ; 3.50(\mathrm{t}, 1 \mathrm{H}, J=7.09$ $\mathrm{Hz}, \mathrm{CH}) ; 2.70$ - $2.60\left(\mathrm{~m}, 4 \mathrm{H}, \mathrm{CH}_{2} \mathrm{NCH}_{2}\right) ; 1.66-1.43\left(\mathrm{~m}, 6 \mathrm{H}, \mathrm{CH}_{2} \mathrm{CH}_{2} \mathrm{CH}_{2}\right) ; 1.41\left(\mathrm{~s}, 3 \mathrm{H}, \mathrm{CH}_{3}\right) ; 1.37$ $\left(\mathrm{s}, 3 \mathrm{H}, \mathrm{CH}_{3}\right) ; 1.12\left(\mathrm{t}, 3 \mathrm{H}, J=7.2 \mathrm{~Hz}, \mathrm{CH}_{3} \mathrm{CH}_{2}\right) .{ }^{13} \mathrm{C}-\mathrm{NMR}\left(\mathrm{CDCl}_{3}\right): \delta, 108.7 ; 69.5 ; 49.5 ; 44.1 ; 33.5$; 29.9; 27.0; 25.7; 23.6; 15.1. MS CI (isobutane) (m/z): $202\left[\mathrm{MH}^{+}\right]$.

\subsubsection{6-(ethylamino)hexane-1,2-diol (25).}

ofCompound 23 (0.64 g; $3.2 \mathrm{mmol}$ ) was dissolved in $20 \mathrm{ml}$ of $80 \%$ TFA in water. The mixture was refluxed for $24 \mathrm{hrs}$, then it was evaporated under reduced pressure. The residue was taken up with $20 \mathrm{ml}$ of water and activated carbon was added; the suspension was heated to boiling and filtered through a bed of celite. The filtrate was evaporated under reduced pressure and the residue was eluted through an ion-exchange column over Amberlite IRA-400 resin to afford $0.42 \mathrm{~g}$ of the title

product as a colourless oil (82\% free base). ${ }^{1} \mathrm{H}-\mathrm{NMR}\left(\mathrm{CD}_{3} \mathrm{OD}\right): \delta, 3.61-3.59(\mathrm{~m}, 1 \mathrm{H}, \mathrm{CHOH}) ; 3.47$ - $3.45\left(\mathrm{~m}, 2 \mathrm{H}, \mathrm{CH}_{2} \mathrm{OH}\right) ; 3.10-2.97\left(\mathrm{~m}, 4 \mathrm{H}, \mathrm{CH}_{2} \mathrm{NHCH}_{2}\right) ; 1.73-1.40\left(\mathrm{~m}, 6 \mathrm{H}, \mathrm{CH}_{2} \mathrm{CH}_{2} \mathrm{CH}_{2}\right) ; 1.31$ 
$\left(\mathrm{t}, 3 \mathrm{H}, J=7.4 \mathrm{~Hz}, \mathrm{CH}_{3}\right) .{ }^{13} \mathrm{C}-\mathrm{NMR}\left(\mathrm{CD}_{3} \mathrm{OD}\right): \delta, 72.8 ; 67.2 ; 48.4 ; 44.0 ; 33.7 ; 27.3 ; 23.6 ; 11.6 . \mathrm{MS}$

CI (isobutane) $(\mathrm{m} / \mathrm{z}): 162\left[\mathrm{MH}^{+}\right]$.

\subsubsection{N-ethyl-5,6-bis(nitrooxy)hexan-1-ammonium nitrate (26).}

To $20 \mathrm{ml}$ of fuming nitric acid cooled at $-15^{\circ} \mathrm{C}, 25(1.5 \mathrm{~g} ; 9.3 \mathrm{mmol})$ was added dropwise over a period of $10 \mathrm{~min}$ The mixture was then allowed to warm to room temperature and was kept under stirring for $40 \mathrm{~h}$. After that period the solvent was distilled under reduced pressure and the residue was dropped and triturated in $150 \mathrm{ml}$ of dry diethyl ether at $-15^{\circ} \mathrm{C}$. The white solid thus obtained was collected through filtration and washed thoroughly with dry diethyl ether to afford $1.97 \mathrm{~g}$ of the title compounds (67\% as nitric acid salt). ${ }^{1} \mathrm{H}-\mathrm{NMR}\left(\mathrm{DMSO}-d_{6}\right): \delta, 8.21$ (br s, $\left.2 \mathrm{H} \mathrm{NH}_{2}{ }^{+}\right) 5.46-5.39$ $\left(\mathrm{m}, 1 \mathrm{H}, \mathrm{CHONO}_{2}\right) ; 4.97-4.92\left(\mathrm{dd}, J_{1}=2.4 \mathrm{~Hz}, J_{2}=12.9 \mathrm{~Hz}, 1 \mathrm{H}, \mathrm{CH}^{\prime} \mathrm{H}^{\prime}{ }^{\prime} \mathrm{ONO}_{2}\right) ; 4.74-4.68(\mathrm{dd}$, $\left.J_{l}=6.2 \mathrm{~Hz}, J_{2}=12.8 \mathrm{~Hz}, 1 \mathrm{H}, \mathrm{CH}^{\prime} H^{\prime}{ }^{\prime} \mathrm{ONO}_{2}\right) ; 2.99-2.85\left(\mathrm{~m}, 4 \mathrm{H}, \mathrm{CH}_{2} \mathrm{NH}_{2}{ }^{+} \mathrm{CH}_{2}\right) 1.78-1.70(\mathrm{~m}$, $\left.2 \mathrm{H}, \mathrm{CH}_{2}\right) ; 1.63-1.37\left(\mathrm{~m}, 6 \mathrm{H}, 2 \mathrm{CH}_{2}\right) 1.16\left(\mathrm{t}, 3 \mathrm{H}, J=7.2 \mathrm{~Hz}, \mathrm{CH}_{3}\right) .{ }^{13} \mathrm{C}-\mathrm{NMR}$ (DMSO-d $)$ : $\delta, 80.0$; 71.8; 45.8; 41.8; 27.6; 25.1; 21.3; 10.9. M.p.: 64 - $65^{\circ}$ C. Anal. Calc. for: $\mathrm{C}_{8} \mathrm{H}_{17} \mathrm{~N}_{3} \mathrm{O}_{6} \cdot \mathrm{HNO}_{3} \cdot 0.5 \mathrm{H}_{2} \mathrm{O}$ C\% 29.72, H\% 5.92, N\% 17.33; Found 29.61, H\% 5.65, N\% 17.53.

\subsubsection{General procedure for the synthesis of the derivatives 28-35.}

The appropriate nitric ester and 27 ( 1 eq.) were suspended in a mixture of $\mathrm{CH}_{3} \mathrm{CN} / \mathrm{DMF} 1 / 1$. To the suspension, cooled at $0{ }^{\circ} \mathrm{C}, 3.5$ eq. of $\mathrm{Et}_{3} \mathrm{~N}$ were added dropwise. The mixture was kept under stirring at room temperature for $6 \mathrm{~h}$. After that period the solvent was distilled under reduced pressure and the residue was taken up with water and extracted with EtOAc. The organic phase was washed with brine, dried over $\mathrm{Na}_{2} \mathrm{SO}_{4}$, filtered and evaporated under reduced pressure. The residue was purified by flash chromatography on silica gel eluting with mixture of DCM/MeOH to afford the desired products as yellow solids in $35-56 \%$ yields. 


\subsubsection{7-chloro-4-\{[4-hydroxy-3-(\{[3-}

(nitrooxy)propyl]ammonio\}methyl)phenyl]amino\}quinolinium dihydrchloride (28).

The free base was taken up with $\mathrm{MeOH}$ and $\mathrm{HCl}$ saturated $\mathrm{Et}_{2} \mathrm{O}$ was added at $0{ }^{\circ} \mathrm{C}$; the solution was kept under stirring at room temperature for two hours, then the solvent was evaporated under reduced pressure and the solid was freeze dried to give the product as the hydrochloride. ${ }^{1} \mathrm{H}-\mathrm{NMR}$ (DMSO-d 6 ): $\delta, 11.20$ (br s, 1H, exch. signal); 10.79 (br s, 1H, exch. signal); 9.50 (br s, 2H, exch. signal) 8.95 (d, $J=9.0 \mathrm{~Hz}, 1 \mathrm{H}$ arom.); 8.46 (d, $J=7.0 \mathrm{~Hz}, 1 \mathrm{H}$ arom.); 8.19 (d, $J=1.9 \mathrm{~Hz}, 1 \mathrm{H}$ arom.); $7.82\left(\mathrm{dd}, J_{l}=9.0 \mathrm{~Hz}, J_{2}=1.9 \mathrm{~Hz}, 1 \mathrm{H}\right.$ arom. $) ; 7.60(\mathrm{~d}, \mathrm{~J}=2.3 \mathrm{~Hz}, 1 \mathrm{H}$ arom. $) ; 7.34\left(\mathrm{~d}, J_{l}=\right.$ $8.6 \mathrm{~Hz}, J_{2}=2.3 \mathrm{~Hz}, 1 \mathrm{H}$ arom.); 7.19 (d, $J=8.6 \mathrm{~Hz}, 1 \mathrm{H}$ arom.); 6.86 (dd, $J=7.0 \mathrm{~Hz}, 1 \mathrm{H}$ arom.); $4.66\left(\mathrm{t}, J=6.0 \mathrm{~Hz}, 2 \mathrm{H}, \mathrm{CH}_{2} \mathrm{ONO}_{2}\right) ; 4.13\left(\mathrm{~s}, 2 \mathrm{H}, \mathrm{CH}_{2} \mathrm{Ph}\right) ; 3.06\left(\mathrm{~m}, 2 \mathrm{H}, \mathrm{CH}_{2} \mathrm{~N}\right) ; 2.17(\mathrm{~m}, 2 \mathrm{H}$, $\left.\mathrm{CCH}_{2} \mathrm{C}\right) .{ }^{13} \mathrm{C}-\mathrm{NMR}\left(\mathrm{DMSO}-d_{6}\right): \delta, 155.4 ; 155.3 ; 154.9 ; 142.9 ; 138.8 ; 138.2 ; 128.7 ; 127.8 ; 127.2$; 125.9; $119.2 ; 119.0 ; 116.4 ; 115.5 ; 100.2 ; 70.7 ; 44.6 ; 43.2 ; 22.8$. M. p.: 177 - $179{ }^{\circ} \mathrm{C}$ (dec.). Anal. Calc. for: $\mathrm{C}_{19} \mathrm{H}_{19} \mathrm{ClN}_{4} \mathrm{O}_{4} \cdot 2 \mathrm{HCl} \cdot 1.7 \mathrm{H}_{2} \mathrm{O} \mathrm{C} \%$ 45.07, $\mathrm{H} \%$ 4.86, N\% 11.06; Found 45.16, $\mathrm{H} \%$ 4.49, N\% 10.69 .

\subsubsection{7-chloro-4-\{[3-(\{ethyl[3-(nitrooxy)propyl]ammonio\}methyl)-4-}

hydroxyphenyl]amino\} quinolinium dihydrochloride (29).

The free base was taken up with $\mathrm{MeOH}$ and $\mathrm{HCl}$ saturated $\mathrm{Et}_{2} \mathrm{O}$ was added at $0{ }^{\circ} \mathrm{C}$; the solution was kept under stirring at room temperature for two hours, then the solvent was evaporated under reduced pressure and the solid was freeze dried to give the product as the hydrochloride. ${ }^{1} \mathrm{H}-\mathrm{NMR}$ (free base) $\left(\mathrm{CDCl}_{3}\right): \delta, 8.42\left(\mathrm{~d}, J=5.6 \mathrm{~Hz}, 1 \mathrm{H}\right.$ arom.); $7.97-7.93\left(\mathrm{~m}, 2 \mathrm{H}\right.$ arom.); 7.41 (dd, $J_{1}=9.0$ $\mathrm{Hz}, J_{2}=2.5 \mathrm{~Hz}, 1 \mathrm{H}$ arom. $) ; 7.14\left(\mathrm{dd}, J_{1}=8.2 \mathrm{~Hz}, J_{2}=2.5 \mathrm{~Hz}, 1 \mathrm{H}\right.$ arom. $) ; 6.96(\mathrm{~d}, J=2.5 \mathrm{~Hz}, 1 \mathrm{H}$ arom.); 6.87 (d, $J=8.2 \mathrm{~Hz}, 1 \mathrm{H}$ arom.); 6.63 (d, $J=5.6 \mathrm{~Hz}, 1 \mathrm{H}$ arom.); 4.49 (t, $J=6.2 \mathrm{~Hz}, 2 \mathrm{H}$, $\left.\mathrm{CH}_{2} \mathrm{ONO}_{2}\right) ; 3.77\left(\mathrm{~s}, 2 \mathrm{H}, \mathrm{CH}_{2} \mathrm{Ph}\right) ; 2.67\left(\mathrm{~m}, 4 \mathrm{H}, \mathrm{CH}_{2} \mathrm{NCH}_{2}\right) ; 1.99\left(\mathrm{~m}, 2 \mathrm{H}, \mathrm{CCH}_{2} \mathrm{C}\right) ; 1.13(\mathrm{t}, J=$ 7.2Hz, 3H, $\left.\mathrm{CH}_{3}\right) .{ }^{13} \mathrm{C}-\mathrm{NMR}$ (free base) $\left(\mathrm{CDCl}_{3}\right): \delta, 156.1 ; 150.7 ; 149.7 ; 148.3 ; 135.5 ; 129.9 ; 127.7 ;$ $125.8 ; 125.7 ; 125.2 ; 125.1 ; 117.1 ; 101.1 ; 70.8 ; 57.2 ; 49.1 ; 47.1 ; 24.0 ; 10.9$. MS CI (free base) 
(isobutane) (m/z): $431 / 433\left[\mathrm{MH}^{+}\right]$. M. p.: 182 - $183{ }^{\circ} \mathrm{C}$ (dec.). Anal. Calc. for:

$\mathrm{C}_{21} \mathrm{H}_{23} \mathrm{ClN}_{4} \mathrm{O}_{4} \cdot 2 \mathrm{HCl} \cdot 1.5 \mathrm{H}_{2} \mathrm{O} \mathrm{C} \%$ 47.51, $\mathrm{H} \%$ 5.31, N\% 10.55; Found 47.62, $\mathrm{H} \%$ 5.02, N\% 10.27.

\subsubsection{7-chloro-4-\{[3-(\{ethyl[6-(nitrooxy)hexyl]ammonio $\}$ methyl)-4-}

hydroxyphenyl] amino\}quinolinium dihydrochloride (30).

The free base was taken up with $\mathrm{MeOH}$ and $\mathrm{HCl}$ saturated $\mathrm{Et}_{2} \mathrm{O}$ was added at $0{ }^{\circ} \mathrm{C}$; the solution was kept under stirring at room temperature for two hours, then the solvent was evaporated under reduced pressure and the solid was freeze dried to give the product as the hydrochloride. ${ }^{1} \mathrm{H}-\mathrm{NMR}$ (CD $\left.{ }_{3} \mathrm{OD}\right): \delta, 8.65$ (d, $J=9.1 \mathrm{~Hz}, 1 \mathrm{H}$ arom.); 8.39 (d, $J=7.1 \mathrm{~Hz}, 1 \mathrm{H}$ arom.); 7.76 (dd, $J_{l}=9.1 \mathrm{~Hz}$, $J_{2}=1.9 \mathrm{~Hz}, 1 \mathrm{H}$ arom.); 7.61 (d, $J=2.5 \mathrm{~Hz}, 1 \mathrm{H}$ arom.); 7.45 (dd, $J_{1}=8.7, \mathrm{~Hz}, J_{2}=2.5 \mathrm{~Hz}, 1 \mathrm{H}$ arom.); 7.15 (d, $J=8.7 \mathrm{~Hz}, 1 \mathrm{H}$ arom.); 6.86 (d, $J=7.1 \mathrm{~Hz}, 1 \mathrm{H}$ arom.); 4.49 (t, $J=6.5 \mathrm{~Hz}, 2 \mathrm{H}$, $\left.\mathrm{CH}_{2} \mathrm{ONO}_{2}\right) ; 4.23\left(\mathrm{~s}, 2 \mathrm{H}, \mathrm{CH}_{2} \mathrm{Ph}\right) ; 3.30-3.20\left(\mathrm{~m}, 4 \mathrm{H}, \mathrm{CH}_{2} \mathrm{NCH}_{2}\right) ; 1.83\left(\mathrm{~m}, 2 \mathrm{H}, \mathrm{CH}_{2}\right) ; 1.74(\mathrm{~m}, 2 \mathrm{H}$, $\left.\mathrm{CH}_{2}\right) 1.42\left(\mathrm{~m}, 7 \mathrm{H}, 2 \mathrm{CH}_{2}, \mathrm{CH}_{3}\right) .{ }^{13} \mathrm{C}-\mathrm{NMR}\left(\mathrm{CD}_{3} \mathrm{OD}\right): \delta, 157.8 ; 157.5 ; 144.2 ; 141.4 ; 140.5 ; 131.4 ;$ $130.5 ; 129.9 ; 129.1 ; 126.5 ; 120.4 ; 119.3 ; 118.0 ; 117.2 ; 101.7 ; 74.5 ; 53.7 ; 52.6 ; 49.8 ; 27.6 ; 27.3 ;$ 26.3; 24.6; 9.2. M. p.: 191 - $193{ }^{\circ} \mathrm{C}$ (dec.). Anal. Calc. for: $\mathrm{C}_{24} \mathrm{H}_{29} \mathrm{ClN}_{4} \mathrm{O}_{4} \cdot 2 \mathrm{HCl} \cdot \mathrm{H}_{2} \mathrm{O} \mathrm{C} \% 51.31$, H\% 5.77, N\% 9.90; Found 51.12, H\% 5.90, N\% 9.94.

\subsubsection{6-[\{5-[(7-chloroquinolin-4-yl)amino]-2-hydroxybenzyl $\}($ ethyl)amino]hexan-1,2-diyl} dinitrate (31).

${ }^{1} \mathrm{H}-\mathrm{NMR}\left(\mathrm{CD}_{3} \mathrm{OD}\right): \delta, 8.32$ - 8.24 (m, 2H arom.); 7.85 (s, 1H arom.); 7.49 - 7.46 (m, 1H arom.); $7.16(\mathrm{~d}, J=4.5 \mathrm{~Hz}, 1 \mathrm{H}$ arom); 7.08 (s, $1 \mathrm{H}$ arom.); $6.88-6.84$ (m, 1H arom.); $6.66-6.64$ (m, $1 \mathrm{H}$ arom.); 5.43 - $5.39\left(\mathrm{~m}, 1 \mathrm{H}, \mathrm{CHONO}_{2}\right) ; 4.96-4.88\left(\mathrm{~m}, 1 \mathrm{H}, \mathrm{CH}_{2} \mathrm{ONO}_{2}\right) ; 4.63-4.56(\mathrm{~m}, 1 \mathrm{H}$, $\left.\mathrm{CH}_{2} \mathrm{ONO}_{2}\right) ; 3.84\left(\mathrm{~s}, 2 \mathrm{H}, \mathrm{PhCH}_{2} \mathrm{~N}\right) ; 2.73$ - $2.61\left(\mathrm{~m}, 4 \mathrm{H}, \mathrm{CH}_{2} \mathrm{NCH}_{2}\right) ; 1.82$ - $1.49(\mathrm{~m}, 6 \mathrm{H}$, $\left.\mathrm{CH}_{2} \mathrm{CH}_{2} \mathrm{CH}_{2}\right) ; 1.19$ - 1.15 (m, 3H, $\left.\mathrm{CH}_{3}\right) .{ }^{13} \mathrm{C}-\mathrm{NMR}\left(\mathrm{DMSO}-d_{6}\right): \delta, 154.8 ; 151.8 ; 149.44 ; 149.38 ;$ $133.7 ; 130.4 ; 127.5 ; 125.4 ; 124.6 ; 124.5 ; 124.2 ; 124.0 ; 117.6 ; 116.0 ; 100.4 ; 80.2 ; 71.8 ; 55.0 ; 51.9 ;$ 
46.4; 28.0; 25.5; 22.1; 10.8. M. p.: $120-122{ }^{\circ} \mathrm{C}$ (dec.). Anal. Calc. for $\mathrm{C}_{24} \mathrm{H}_{28} \mathrm{ClN}_{5} \mathrm{O}_{7} \mathrm{C} \%$ 53.09, H\% 5.38, N\% 12.90; Found C\% 52.79, H\% 5.12, N\% 12.61.

\subsubsection{7-chloro-4-\{[4-hydroxy-3-(\{4-[(nitrooxy)methyl]piperidinium-1-} yl\}methyl)phenyl]amino \}quinolinium dihydrochloride (32).

The free base was taken up with $\mathrm{MeOH}$ and $\mathrm{HCl}$ saturated $\mathrm{Et}_{2} \mathrm{O}$ was added at $0{ }^{\circ} \mathrm{C}$; the solution was kept under stirring at room temperature for two hours, then the solvent was evaporated under reduced pressure and the solid was freeze dried to give the product as the hydrochloride. ${ }^{1} \mathrm{H}-\mathrm{NMR}$ (free base) (DMSO- $\left.d_{6}\right): \delta, 8.90$ (s, $1 \mathrm{H}$ arom.); $8.43-8.36$ (m, $2 \mathrm{H}$ arom.); 7.85 (d, $J=1.8 \mathrm{~Hz}, 1 \mathrm{H}$ arom.); 7.52 (dd, $J_{l}=7.2, \mathrm{~Hz}, J_{2}=1.8 \mathrm{~Hz}, 1 \mathrm{H}$ arom.); $7.10-7.08$ (m, 2H arom.); 6.82 (d, $J=9.2$ $\mathrm{Hz}, 1 \mathrm{H}$ arom.); 6.57 (d, $J=5.4 \mathrm{~Hz}, 1 \mathrm{H}$ arom.); $4.42\left(\mathrm{~d}, J=6.3 \mathrm{~Hz}, 2 \mathrm{H}, \mathrm{CH}_{2} \mathrm{ONO}_{2}\right) ; 3.64$ (s, 2H, $\mathrm{CH}_{2} \mathrm{Ph}$ ); $2.91-2.51$ (m, 2H, $\mathrm{CH}_{2}$-piperidine); $2.11-2.04$ (m, 2H, $\mathrm{CH}_{2}$-piperidine); 1.79 - 1.70 (m, $3 \mathrm{H}, \mathrm{CH}$-piperidine, $\mathrm{CH}_{2}$-piperidine) $1.32-1.28\left(\mathrm{~m}, 2 \mathrm{H}, \mathrm{CH}_{2}\right.$-piperidine). ${ }^{13} \mathrm{C}-\mathrm{NMR}$ (free base) (DMSO-d $\left.d_{6}\right): \delta, 154.0 ; 151.8 ; 149.4 ; 149.0 ; 133.7 ; 131.2 ; 129.4 ; 127.8 ; 127.5 ; 124.7 ; 124.1 ; 117.7$; 116.8; 116.4; 100.8; 77.2; 65.3; 59.3; 54.0; 34.7; 28.2. M. p.: 170 - $172{ }^{\circ} \mathrm{C}$ (dec.). Anal. Calc. for: $\mathrm{C}_{22} \mathrm{H}_{25} \mathrm{ClN}_{4} \mathrm{O}_{4} \cdot 2 \mathrm{HCl} \cdot 2 \mathrm{H}_{2} \mathrm{O}$ C\% 47.88, $\mathrm{H} \% 5.30 \mathrm{~N} \%$ 10.15; Found 47.60, $\mathrm{H} \%$ 4.87, N\% 10.07.

\subsubsection{7-chloro-4-\{[4-hydroxy-3-(\{4-[2-(nitrooxy)ethyl]piperidinium-1-}

yl\}methyl)phenyl]amino \}quinolinium dihydrochloride (33).

The free base was taken up with $\mathrm{MeOH}$ and $\mathrm{HCl}$ saturated $\mathrm{Et}_{2} \mathrm{O}$ was added at $0{ }^{\circ} \mathrm{C}$; the solution was kept under stirring at room temperature for two hours, then the solvent was evaporated under reduced pressure and the solid was freeze dried to give the product as the hydrochloride. ${ }^{1} \mathrm{H}-\mathrm{NMR}$ (free base) $\left(\mathrm{CD}_{3} \mathrm{OD}+\mathrm{CDCl}_{3}\right): \delta, 8.28(\mathrm{~d}, J=5.6 \mathrm{~Hz}, 1 \mathrm{H}$ arom.); $8.21(\mathrm{~d}, J=9.0 \mathrm{~Hz}, 1 \mathrm{H}$ arom.); $7.83\left(\mathrm{~d}, J=2.0 \mathrm{~Hz}, 1 \mathrm{H}\right.$ arom.); 7.44 (dd, $J_{l}=6.9, \mathrm{~Hz}, J_{2}=2.1 \mathrm{~Hz}, 1 \mathrm{H}$ arom.); 7.13 (dd, $J_{l}=6.0$, $\mathrm{Hz}, J_{2}=2.5 \mathrm{~Hz}, 1 \mathrm{H}$ arom.); 7.02 (d, $J=2.4 \mathrm{~Hz}, 1 \mathrm{H}$ arom.); 6.84 (d, $J=8.5 \mathrm{~Hz}, 1 \mathrm{H}$ arom.); 6.62 (d, $J=5.6 \mathrm{~Hz}, 1 \mathrm{H}$ arom.) $4.54\left(\mathrm{t}, J=6.5 \mathrm{~Hz}, 2 \mathrm{H}, \mathrm{CH}_{2} \mathrm{ONO}_{2}\right) ; 3.73\left(\mathrm{~s}, 2 \mathrm{H}, \mathrm{CH}_{2} \mathrm{Ph}\right) ; 3.07-3.03(\mathrm{~m}, 2 \mathrm{H}$, 
$\mathrm{CH}_{2}$-piperidine) $2.21-2.14$ (m, 2H, $\mathrm{CH}_{2}$-piperidine); $1.85-1.81$ (m, 2H, $\mathrm{CH}_{2}$-piperidine); 1.74 1.68 (m, 2H, $\mathrm{CH}_{2}$-lateral chain); $1.63-1.55$ (m, 1H, CH-piperidine); $1.46-1.33$ (m, 2H, $\mathrm{CH}_{2-}$ piperidine). ${ }^{13} \mathrm{C}-\mathrm{NMR}$ (free base) $\left(\mathrm{CD}_{3} \mathrm{OD}+\mathrm{CDCl}_{3}\right): \delta, 157.2 ; 156.3 ; 143.1 ; 141.1 ; 140.8 ; 139.7$; $131.0 ; 129.3 ; 128.8 ; 125.8 ; 119.8 ; 117.5 ; 117.4 ; 116.5 ; 101.2 ; 71.1 ; 57.9 ; 55.3 ; 53.0 ; 49.7 ; 32.9$; 31.2; 29.5. MS CI (free base) (isobutane) (m/z): $457 / 459\left[\mathrm{MH}^{+}\right]$. M. p.: 163 - $164{ }^{\circ} \mathrm{C}$ (dec.). Anal. Calc. for: $\mathrm{C}_{23} \mathrm{H}_{25} \mathrm{ClN}_{4} \mathrm{O}_{4} \cdot 2 \mathrm{HCl} \mathrm{C} \% 52.14, \mathrm{H} \% 5.14 \mathrm{~N} \%$ 10.57; Found 51.79, $\mathrm{H} \%$ 5.34, N\% 10.17.

\subsubsection{7-chloro-4-\{[4-hydroxy-3-(\{4-[2-(nitrooxy)ethyl]piperazinedium-1-}

yl\}methyl)phenyl]amino\}quinolinium trihydrochloride (34).

The free base was taken up with $\mathrm{MeOH}$ and $\mathrm{HCl}$ saturated $\mathrm{Et}_{2} \mathrm{O}$ was added at $0{ }^{\circ} \mathrm{C}$; the solution was kept under stirring at room temperature for two hours, then the solvent was evaporated under reduced pressure and the solid was freeze dried to give the product as the hydrochloride. ${ }^{1} \mathrm{H}-\mathrm{NMR}$ (free base) $\left(\mathrm{CD}_{3} \mathrm{OD}\right): \delta, 8.30-8.23\left(\mathrm{~m}, 2 \mathrm{H}\right.$ arom.); $7.82\left(\mathrm{~d}, J=2.1 \mathrm{~Hz}, 1 \mathrm{H}\right.$ arom.); 7.50 (dd, $J_{1}=$ $6.9 \mathrm{~Hz}, J_{2}=2.1 \mathrm{~Hz}, 1 \mathrm{H}$ arom.); $7.15-6.90$ (m, 2H arom.); 6.84 (d, J=8.5, Hz, 1H arom.); 6.62 (d, $J=5.6 \mathrm{~Hz}, 1 \mathrm{H}$ arom.); $4.63\left(\mathrm{t}, J=6.5 \mathrm{~Hz}, 2 \mathrm{H}, \mathrm{CH}_{2} \mathrm{ONO}_{2}\right) ; 3.74\left(\mathrm{~s}, 2 \mathrm{H}, \mathrm{CH}_{2} \mathrm{Ph}\right) ; 2.76(\mathrm{t}, \mathrm{J}=5.4 \mathrm{~Hz}$, $\left.2 \mathrm{H}, \mathrm{CH}_{2} \mathrm{CH}_{2} \mathrm{ONO}_{2}\right) 2.57$ (br s 8H, 4CH 2 -piperazine). ${ }^{13} \mathrm{C}-\mathrm{NMR}$ (free base) $\left(\mathrm{CD}_{3} \mathrm{OD}\right): \delta, 156.7$; $152.6 ; 152.2 ; 149.9 ; 136.7 ; 132.1 ; 127.6 ; 127.5 ; 126.9 ; 126.5 ; 124.6 ; 124.1 ; 119.0 ; 117.6 ; 101.8$; 71.4; 60.9; 59.8; 55.9; 54.2; 53.8; 53.3. MS CI (free base) (isobutane) (m/z): $458\left[\mathrm{MH}^{+}\right]$. M. p.: 153 - $154{ }^{\circ} \mathrm{C}$ (dec.). Anal. Calc. for: $\mathrm{C}_{22} \mathrm{H}_{24} \mathrm{ClN}_{5} \mathrm{O}_{4} \cdot 3 \mathrm{HCl} \cdot 2.5 \mathrm{H}_{2} \mathrm{O} \mathrm{C} \%$ 43.15, $\mathrm{H} \% 5.27 \mathrm{~N} \%$ 11.44; Found 42.87, H\% 4.93, N\% 11.20.

\subsubsection{7-chloro-4-\{[4-hydroxy-3-(\{4-[3-(nitrooxy)propyl]piperazinediium-1-} yl\}methyl)phenyl]amino\}quinolinium trihydrochloride (35).

The free base was taken up with $\mathrm{MeOH}$ and $\mathrm{HCl}$ saturated $\mathrm{Et}_{2} \mathrm{O}$ was added at $0{ }^{\circ} \mathrm{C}$; the solution was kept under stirring at room temperature for two hours, then the solvent was evaporated under reduced pressure and the solid was freeze dried to give the product as the hydrochloride. ${ }^{1} \mathrm{H}-\mathrm{NMR}$ 
(free base) (DMSO- $\left.d_{6}\right): \delta, 8.91$ (br s, exch. sign. 1H) 8.43 - 8.36 (m, 2H arom.); 7.85 (s, 1H arom.); $7.54-7.51$ (m, 1H arom.); $7.11-7.09$ (m, 2H arom.); 6.84 (d, J=8.9, Hz, 1H arom.); $6.60-6.59$ (m, $1 \mathrm{H}$ arom.); $4.55\left(\mathrm{t}, J=6.2 \mathrm{~Hz}, 2 \mathrm{H}, \mathrm{CH}_{2} \mathrm{ONO}_{2}\right) ; 3.64\left(\mathrm{~s}, 2 \mathrm{H}, \mathrm{CH}_{2} \mathrm{Ph}\right) ; 2.51-2.38(\mathrm{~m}, 10 \mathrm{H}$, $\left.5 \mathrm{CH}_{2}\right) 1.85-1.81\left(\mathrm{~m} 2 \mathrm{H}, \mathrm{CH}_{2}\right) .{ }^{13} \mathrm{C}-\mathrm{NMR}$ (free base) (DMSO- $\left.d_{6}\right): \delta, 155.7 ; 154.8 ; 153.3 ; 150.9$; $135.4 ; 132.0 ; 129.0 ; 127.9 ; 127.3 ; 126.1 ; 125.8 ; 124.9 ; 119.2 ; 117.5 ; 102.0 ; 73.9 ; 59.8 ; 56.8 ; 55.2 ;$ 53.8; 48.3; 25.1; 14.9. M. p.: 167 - $168{ }^{\circ} \mathrm{C}$ (dec.). Anal. Calc. for: $\mathrm{C}_{22} \mathrm{H}_{24} \mathrm{ClN}_{5} \mathrm{O}_{4} \cdot 3 \mathrm{HCl} \cdot 2.5 \mathrm{H}_{2} \mathrm{O} \mathrm{C} \%$ 44.10, H\% 5.47 N\% 11.18; Found 43.81, H\% 4.99, N\% 10.88.

\subsubsection{4-[(7-Chloroquinolin-4-yl)amino]-2-\{[ethyl-(2-hydroxyethyl)amino]methyl $\}$ phenol} dihydrochloride (36)

To a stirred solution of 2-(ethylamino)ethanol $(0.82 \mathrm{~mL} ; 8.43 \mathrm{mmol})$ in $\mathrm{CH}_{3} \mathrm{CN}(20 \mathrm{~mL})$, kept under nitrogen, 27 ( $1 \mathrm{~g} ; 2.81 \mathrm{mmol})$ was added. The yellow suspension was stirred for $18 \mathrm{~h}$. The solvent was evaporated and the yellow residue was treated with water $(15 \mathrm{~mL})$ and stirred for 15 min. The solid was collected on a buchner funnel and washed with water $(50 \mathrm{~mL})$. After drying over $\mathrm{P}_{2} \mathrm{O}_{5}$ the product was purified by flash chromatography eluting with $\mathrm{CH}_{2} \mathrm{Cl}_{2} / \mathrm{MeOH} 20 \%$ to give $36(0.72 \mathrm{~g} ; 69 \%)$ as yellow solid. The product was converted into the corresponding hydrochloride by treatment with $\mathrm{HCl}$ saturated $\mathrm{MeOH}$ and recrystallised from dry $\mathrm{MeOH} / \mathrm{Et}_{2} \mathrm{O}$ to obtain an analytical sample. Mp: $228-229.5^{\circ} \mathrm{C}$ (dec.) $\left(230{ }^{\circ} \mathrm{C}\right.$ dec. [30]). ${ }^{1} \mathrm{H}$ NMR (DMSO$\left.d_{6}+\mathrm{D}_{2} \mathrm{O}\right): \delta, 8.33\left(\mathrm{~d}, 1 \mathrm{H}, J=9.1 \mathrm{~Hz}, \mathrm{AQ}-\mathrm{H}_{5}\right) ; 8.21\left(\mathrm{~d}, 1 \mathrm{H}, J=7.1 \mathrm{~Hz}, \mathrm{AQ}-\mathrm{H}_{2}\right) ; 7.82(\mathrm{~d}, 1 \mathrm{H}, J=2$ Hz, AQ-H 8 ); 7.65 (dd, 1H, $\left.J=2,9.1 \mathrm{~Hz}, \mathrm{AQ}-\mathrm{H}_{6}\right) ; 7.38$ (d, 1H, $\left.J=2.5 \mathrm{~Hz}, \mathrm{AQ}-\mathrm{H}_{3}{ }^{\prime}\right) ; 7.34$ (dd, 1H, $J$ $=2.5,8.6 \mathrm{~Hz}$ AQ- $\left.\mathrm{H}_{5}{ }^{\prime}\right) ; 7.06\left(\mathrm{~d}, 1 \mathrm{H}, J=8.6 \mathrm{~Hz}, \mathrm{AQ}-\mathrm{H}_{6}{ }^{\prime}\right) ; 6.72\left(\mathrm{~d}, 1 \mathrm{H}, J=7.1 \mathrm{~Hz}, \mathrm{AQ}-\mathrm{H}_{3}\right) ; 4.32(\mathrm{~s}$, $\left.2 \mathrm{H}, \mathrm{CH}_{2} \mathrm{Ph}\right) ; 3.79\left(\mathrm{t}, 2 \mathrm{H}, J=5.1 \mathrm{~Hz}, \mathrm{CH}_{2} \mathrm{O}\right) ; 3.2\left(\mathrm{~m}, 4 \mathrm{H}, 2\left(\mathrm{CH}_{2} \mathrm{~N}\right)\right) ; 1.26\left(\mathrm{t}, 3 \mathrm{H}, J=7.2 \mathrm{~Hz}, \mathrm{CH}_{3}\right)$. ${ }^{13} \mathrm{C}$ NMR (DMSO- $d_{6}+\mathrm{D}_{2} \mathrm{O}$ ): $\delta, 154.0$ (two overlapping peaks); $141.2 ; 138.1 ; 136.9 ; 128.1 ; 127.5$; $126.9 ; 126.5 ; 123.3 ; 117.6 ; 116.2 ; 115.5 ; 113.9 ; 98.7 ; 53.6 ; 52.3 ; 50.6 ; 47.0 ; 6.9$. MS (free base) 
(EI) m/z : 371 (52), 340 (35), 283 (100). Anal. Calc. For $\mathrm{C}_{20} \mathrm{H}_{22} \mathrm{ClN}_{3} \mathrm{O}_{2} \cdot 2 \mathrm{HCl} \cdot 0.1 \mathrm{H}_{2} \mathrm{O} \mathrm{C} \%$

53.78, H\% 5.46, N\% 9.40; found C\% 53.58, H\% 5.39, N\% 9.33.

\subsubsection{4-[(7-Chloroquinolin-4-yl)amino]-2-[(\{ethyl-[2-(3-phenylfuroxan-4-}

yl)oxy]ethyl\}amino)methyl]phenol dihydrochloride (37).

To a suspension of $\mathbf{3 6}(1.3 \mathrm{~g} ; 2.92 \mathrm{mmol})$ in distilled THF/DMF 14/1 (27.5 mL), stirred under nitrogen at RT, $50 \% \mathrm{NaOH}$ aqueous solution (14.6 mmol) was added dropwise followed by a solution of 3-phenyl-4-benzenesulfonyl furoxan (1.24 g; $4.1 \mathrm{mmol})$ in distilled THF. The reaction mixture was stirred for $5 \mathrm{~h}$, then the mixture was concentrated under reduced pressure to leave a brown oil. This residue was taken up with water $(20 \mathrm{~mL})$ and extracted with EtOAc $(4 \times 30 \mathrm{~mL})$. The organic phase was washed with brine $(40 \mathrm{~mL})$, dried and evaporated under reduced pressure to afford the crude product as brown solid. The solid was purified by flash chromatography eluting with $\mathrm{CH}_{2} \mathrm{Cl}_{2} / \mathrm{MeOH} 3 \%$. The fractions containing the desired product were collected in tubes filled with $0.2 \mathrm{~mL}$ of $\mathrm{HCl}$ saturated $\mathrm{MeOH}$ to readily convert the product into the corresponding dihydrochloride. After evaporation under reduced pressure 37 was obtained in 50\% yield as brightyellow solid. The product was recrystallised from $\mathrm{MeOH} / \mathrm{Et}_{2} \mathrm{O}$. Mp: $229-231{ }^{\circ} \mathrm{C}$ (dec.) ${ }^{1} \mathrm{H} \mathrm{NMR}$ (DMSO-d $)_{6}$ ) $\delta, 11.24$ (s, 1H, exch. signal); 11.15 (br s, 1H, exch. signal); 10.98 (br s, 1H, exch. signal); $8.94\left(\mathrm{~d}, 1 \mathrm{H}, \mathrm{J}=8.8 \mathrm{~Hz}, \mathrm{AQ}-\mathrm{H}_{5}\right) ; 8.4\left(\mathrm{~d}, 1 \mathrm{H}, \mathrm{J}=6.5 \mathrm{~Hz}, \mathrm{AQ}-\mathrm{H}_{2}\right) ; 8.18\left(\mathrm{~s}, 1 \mathrm{H}, \mathrm{AQ}-\mathrm{H}_{8}\right) ; 8.02$ $\left(\mathrm{d}, 2 \mathrm{H}, \mathrm{J}=6.8 \mathrm{~Hz}, \mathrm{FxPh}-\mathrm{H}_{\mathrm{o}}\right) ; 7.81\left(\mathrm{~d}, 1 \mathrm{H}, \mathrm{J}=8.8 \mathrm{~Hz}, \mathrm{AQ}-\mathrm{H}_{6}\right) ; 7.71\left(\mathrm{~s}, 1 \mathrm{H}, \mathrm{AQ}-\mathrm{H}_{3}{ }^{\prime}\right) ; 7.52(\mathrm{~m}, 3 \mathrm{H}$, FxPh-H $\left.{ }_{\mathrm{m}} ; \mathrm{FxPhH}_{\mathrm{p}}\right) ; 7.38\left(\mathrm{~d}, 1 \mathrm{H}, \mathrm{J}=8.4 \mathrm{~Hz}, \mathrm{AQ}-\mathrm{H}_{5}{ }^{\prime}\right) ; 7.22\left(\mathrm{~d}, 1 \mathrm{H}, \mathrm{J}=8.4 \mathrm{~Hz}, \mathrm{AQ}-\mathrm{H}_{6}{ }^{\prime}\right) ; 6.89$ (d, $\left.1 \mathrm{H}, \mathrm{J}=6.5 \mathrm{~Hz}, \mathrm{AQ}-\mathrm{H}_{3}\right) ; 4.97$ (br m, 2H, $\left.\mathrm{CH}_{2} \mathrm{O}\right) ; 4.26\left(\mathrm{~s}, 2 \mathrm{H}, \mathrm{PhCH}_{2} \mathrm{~N}\right) ; 3.74\left(\mathrm{br} \mathrm{m}, 2 \mathrm{H}, \mathrm{CH}_{2} \mathrm{~N}\right)$; 3.29 (br m, $2 \mathrm{H}, \mathrm{CH}_{3} \mathrm{CH}_{2} \mathrm{~N}$ ); 1.36 (br m, 3H, $\mathrm{CH}_{3}$ ). ${ }^{13} \mathrm{C}$ NMR (DMSO-d 6 ): $\delta, 161.6 ; 155.9 ; 154.6$; $142.8 ; 138.7 ; 138.1 ; 130.5 ; 130.1 ; 128.7 ; 128.4 ; 127.8 ; 127.0 ; 126.3 ; 126.2 ; 121.5 ; 118.9 ; 117.0 ;$ $116.7 ; 115.5 ; 107.6 ; 100.4 ; 65.2 ; 50.2 ; 49.6 ; 47.9 ; 8.5$. Anal. Calc. For $\mathrm{C}_{28} \mathrm{H}_{26} \mathrm{ClN}_{5} \mathrm{O}_{4} \cdot 2 \mathrm{HCl} \mathrm{C} \%$ 55.59, H\% 4.66, N\% 11.58; found C\% 55.29, H\% 4.64, N\% 11.44. 


\subsubsection{2-\{[(3-Phenylsulfonylfuroxan-4-yl)oxy]ethyl\}ethylamine hydrochloride (39)}

To a stirred solution of 3,4-bis(phenylsulfonyl)furoxan (38) $(1 \mathrm{~g} ; 2.72 \mathrm{mmol})$ in dist. THF (14 $\mathrm{mL})$ kept under nitrogen, 2-(ethylamino)ethanol (0.54 mL; $5.52 \mathrm{mmol})$ was added. The obtained mixture was cooled to $15^{\circ} \mathrm{C}$ and $50 \% \mathrm{NaOH}$ aqueous solution $(0.64 \mathrm{~g} ; 8.16 \mathrm{mmol})$ was added dropwise. The reaction mixture was stirred for further $40 \mathrm{~min}$ and the solvent evaporated under reduced pressure to give a yellow solid. The solid was taken up with water $(30 \mathrm{~mL})$ and extracted with $\mathrm{CH}_{2} \mathrm{Cl}_{2}(4 \times 30 \mathrm{~mL})$, dried $\left(\mathrm{Na}_{2} \mathrm{SO}_{4}\right)$ and evaporated to give the crude product as an oil. The product was purified by $\mathrm{FC}$ eluting with $\mathrm{CH}_{2} \mathrm{Cl}_{2} / \mathrm{MeOH} 5 \%$ to obtain the title product $(0.4 \mathrm{~g} ; 48 \%)$ as colorless oil. The product was either used immediately in the next step or stored at $-21{ }^{\circ} \mathrm{C}$ overnight. An analytical sample was obtained as the hydrochloride by treatment with $\mathrm{HCl}$ saturated $\mathrm{MeOH}$, precipitation with dry $\mathrm{Et}_{2} \mathrm{O}$ and recrystallisation from dry $\mathrm{MeOH} / \mathrm{Et}_{2} \mathrm{O}$. Mp: 136.8-138. ${ }^{1} \mathrm{H}$ NMR (DMSO- $\left.d_{6}\right): \delta, 9.49\left(s, 2 \mathrm{H}\right.$, exch. signal); $8.08\left(d, 2 \mathrm{H}, J=7.5 \mathrm{~Hz}, \mathrm{Ph}-\mathrm{H}_{\mathrm{o}}\right) ; 7.91(t, 1 \mathrm{H}, J=7.5$ $\left.\mathrm{Hz}, \mathrm{Ph}-\mathrm{H}_{\mathrm{p}}\right) ; 7.76\left(t, 2 \mathrm{H}, J=7.7 \mathrm{~Hz}, \mathrm{Ph}-\mathrm{H}_{\mathrm{m}}\right) ; 4.78\left(t, 2 \mathrm{H}, J=4.9 \mathrm{~Hz}, \mathrm{CH}_{2} \mathrm{O}\right) ; 3.35\left(m, 2 \mathrm{H}, \mathrm{CH}_{2} \mathrm{~N}\right)$; $3.08\left(q, 2 \mathrm{H}, J=7.2 \mathrm{~Hz}, \mathrm{NCH}_{2} \mathrm{CH}_{3}\right) ; 1.27\left(t, 3 \mathrm{H}, J=7.2, \mathrm{CH}_{3}\right) .{ }^{13} \mathrm{C}$ NMR (DMSO- $\left.d_{6}\right): \delta, 158.5$; $136.8 ; 136.1 ; 129.9 ; 128.5 ; 110.8 ; 67.0 ; 44.2 ; 42.3 ; 11.0$. Anal. Calc. For $\mathrm{C}_{12} \mathrm{H}_{15} \mathrm{~N}_{3} \mathrm{O}_{5} \mathrm{~S} \cdot \mathrm{HCl} \mathrm{C} \%$ 41.21, H\% 4.61, N\% 12.01; found C\% 41.51, H\% 4.81, N\% 11.88.

\subsubsection{4-[(7-Chloroquinolin-4-yl)amino]-2-\{[(\{[2-(3-phenylsulfonylfuroxan-4-} yl)oxy]ethyl\}ethyl)amino]methyl\}phenol dihydrochloride (40)

To a suspension of $27(0.9 \mathrm{~g} ; 2.53 \mathrm{mmol})$ in iPrOH/DMF 10/1 (16.5 mL), stirred under nitrogen at RT, triethylamine $(10.1 \mathrm{mmol})$ was added. After $15 \mathrm{~min}$ of stirring a solution of $\mathbf{3 9}(0.7 \mathrm{~g} ; 3.54$ $\mathrm{mmol})$ in $\mathrm{iPrOH} / \mathrm{DMF} 10 / 1(10 \mathrm{~mL})$ was added dropwise at RT. The reaction mixture was stirred for $24 \mathrm{~h}$, the solvent evaporated under reduced pressure to leave an oily residue which was taken up with water $(20 \mathrm{~mL})$ and extracted with EtOAc $(4 \times 30 \mathrm{~mL})$. The organic phase was washed with 
brine $(40 \mathrm{~mL})$, dried and evaporated under reduced pressure to give the crude product as lightbrown oil. The product was purified by flash chromatography eluting with $\mathrm{CH}_{2} \mathrm{Cl}_{2} / \mathrm{MeOH} 3 \%$. The fractions containing the desired product were collected in tubes filled with $0.2 \mathrm{~mL}$ of $\mathrm{HCl}$ saturated $\mathrm{MeOH}$ to readily convert the product into the corresponding dihydrochloride. After evaporation under reduced pressure $\mathbf{4 0}$ was obtained in $40 \%$ yield as white solid. The product was recrystallised from MeOH. Mp: $214-215{ }^{\circ} \mathrm{C}$ (dec. $){ }^{1} \mathrm{H}$ NMR $\left(\mathrm{CD}_{3} \mathrm{OD}+\mathrm{D}_{2} \mathrm{O}\right): \delta, 8.54$ (d, $\left.1 \mathrm{H}, J=9.1 \mathrm{~Hz}, \mathrm{AQ}-\mathrm{H}_{5}\right)$; $8.3\left(\mathrm{~d}, 1 \mathrm{H}, J=7.1 \mathrm{~Hz}, \mathrm{AQ}-\mathrm{H}_{2}\right) ; 7.98\left(\mathrm{~d}, 2 \mathrm{H}, J=7.4 \mathrm{~Hz}, \mathrm{FxPh}-\mathrm{H}_{\mathrm{o}}\right) ; 7.94\left(\mathrm{~d}, 1 \mathrm{H}, J=2 \mathrm{~Hz}, \mathrm{AQ}-\mathrm{H}_{8}\right)$; 7.81-7.74 (m, 2H, AQ- ${ }_{6}$, FxPh- $\left.\mathrm{H}_{\mathrm{p}}\right)$; 7.69-7.62 (m, 3H, AQ- ${ }_{3}{ }^{\prime}$, FxPh- $\left.\mathrm{H}_{\mathrm{m}}\right)$; 7.48-7.45 (m, 1H, AQ$\left.\mathrm{H}_{5}{ }^{\prime}\right) ; 7.17\left(\mathrm{~d}, 1 \mathrm{H}, J=8.7 \mathrm{~Hz}, \mathrm{AQ}-\mathrm{H}_{6}{ }^{\prime}\right) ; 6.83\left(\mathrm{~d}, 1 \mathrm{H}, J=7.1 \mathrm{~Hz}, \mathrm{AQ}-\mathrm{H}_{3}\right) ; 4.95\left(\mathrm{br} \mathrm{m}, 2 \mathrm{H}, \mathrm{CH}_{2} \mathrm{O}\right)$; $4.64\left(\mathrm{~s}, 2 \mathrm{H}, \mathrm{PhCH}_{2} \mathrm{~N}\right) ; 3.83\left(\right.$ br m, $\left.2 \mathrm{H}, \mathrm{OCH}_{2} \mathrm{CH}_{2} \mathrm{~N}\right) ; 3.49\left(\mathrm{q}, 2 \mathrm{H}, J=7.2 \mathrm{~Hz}, \mathrm{CH}_{3} \mathrm{CH}_{2} \mathrm{~N}\right) ; 1.38(\mathrm{t}$, $3 \mathrm{H}, J=7.2 \mathrm{~Hz} \mathrm{CH})_{3} .{ }^{13} \mathrm{C} \mathrm{NMR}\left(\mathrm{CD}_{3} \mathrm{OD}+\mathrm{D}_{2} \mathrm{O}\right): \delta, 159.6 ; 157.7 ; 157.6 ; 143.9 ; 141.4 ; 140.3 ; 138.2 ;$ $137.3 ; 131.3 ; 131.0 ; 130.6 ; 129.9 ; 129.6 ; 129.2 ; 126.2 ; 120.4 ; 119.2 ; 118.2 ; 117.0 ; 111.9 ; 101.6$; 67.1; 54.1; 52.0; 51.0; 9.6. Anal. Calc. For $\mathrm{C}_{28} \mathrm{H}_{26} \mathrm{ClN}_{5} \mathrm{O}_{6} \mathrm{~S} \cdot 2 \mathrm{HCl} \mathrm{C} \% 50.27, \mathrm{H} \%$ 4.22, N\% 10.47; found $\mathrm{C} \%$ 50.29, $\mathrm{H} \%$ 4.23, N\% 10.27.

\subsection{Dissociation constants determination}

The ionisation constants of compounds were determined by potentiometric titration with the GLpK $K_{\mathrm{a}}$ apparatus (Sirius Analytical Instruments Ltd, Forrest Row, East Sussex, UK). Apparent ionisation constants $\left(\mathrm{p}_{\mathrm{s}} K_{\mathrm{a}}\right)$ were obtained in co-solvent mixtures because of the low aqueous solubility of compounds according to the following procedure. At least five separate $20 \mathrm{~mL}$ semiaqueous solutions of the compounds (about $1 \mathrm{mM}$ in $17-65 \mathrm{Wt} \%$ methanol for chloroquine derivatives and 40-65 Wt\% methanol for amodiaquine derivatives) were initially acidified to $\mathrm{pH} 1.8$ with $0.5 \mathrm{~N} \mathrm{HCl}$. The solutions were then titrated with standardised $0.5 \mathrm{~N} \mathrm{KOH}$ to $\mathrm{pH} 10.5$. The titrations were performed under argon at $25.0 \pm 0.1{ }^{\circ} \mathrm{C}$. The initial estimates of the apparent ionisation constants $\left(\mathrm{p}_{\mathrm{s}} K_{\mathrm{a}}\right)$ were obtained by Bjerrum plots; these values were finally refined by a 
weighted non-linear least-squares procedure. Aqueous $p K_{\mathrm{a}}$ values were obtained by extrapolation using the Yasuda-Shedlovsky procedure [31]. The molar $\%$ of species were calculated using the experimental $p K_{\mathrm{a}}$ values from the Henderson-Hasselbalch equation.

\subsubsection{Parasite cultures}

$P$. falciparum cultures were carried out according to Trager and Jensen's with slight modifications [32]. The CQ-sensitive, strain D10 and the CQ-resistant, strain W2 were maintained at $5 \%$ hematocrit (human type A-positive red blood cells) in RPMI 1640 (EuroClone, Celbio) medium with the addition of 1\% AlbuMax (Invitrogen, Milan, Italy), 0.01\% hypoxantine, $20 \mathrm{mM}$ Hepes, and $2 \mathrm{mM}$ glutammine. All the cultures were maintained at $37^{\circ} \mathrm{C}$ in a standard gas mixture consisting of $1 \% \mathrm{O}_{2}, 5 \% \mathrm{CO}_{2}, 94 \% \mathrm{~N}_{2}$.

\subsubsection{Parasite growth and drug susceptibility assay}

Compounds were dissolved in either water (chloroquine) or DMSO and then diluted with medium to achieve the required concentrations (final DMSO concentration $<1 \%$, which is non-toxic to the parasite). Drugs were placed in 96 wells flat-bottom microplates (COSTAR) and serial dilutions made. Asynchronous cultures with parasitemia of 1-1.5\% and $1 \%$ final haematocrit were aliquoted into the plates and incubated for 72 hours at $37^{\circ} \mathrm{C}$. Parasite growth was determined spectrophotometrically $\left(\mathrm{OD}_{650}\right)$ by measuring the activity of the parasite lactate dehydrogenase $(\mathrm{pLDH})$, according to a modified version of Makler's method in control and drug-treated cultures $[33,34]$. Antimalarial activity is expressed as the $50 \%$ inhibitory concentrations $\left(\mathrm{IC}_{50}\right)$; each $\mathrm{IC}_{50}$ value is the mean and standard deviation of at least three separate experiments.

\subsubsection{Vasodilator activity assay.}


Thoracic aortas were isolated from male Wistar rats weighing 180-200 g. The endothelium was removed and the vessels were elically cut: three strips were obtained from each aorta. The tissues were mounted in organ baths containing $30 \mathrm{~mL}$ of Krebs-bicarbonate buffer of the following composition (mM): $\mathrm{NaCl} 111.2, \mathrm{KCl} 5.0, \mathrm{CaCl}_{2} 2.5, \mathrm{MgSO}_{4} 1.2, \mathrm{KH}_{2} \mathrm{PO}_{4} 1.0, \mathrm{NaHCO}_{3}$ 12, glucose 11.1 maintained at $37{ }^{\circ} \mathrm{C}$ and continuously gassed with $95 \% \mathrm{O}_{2}-5 \% \mathrm{CO}_{2}(\mathrm{pH}=7.4)$. The aortic strips were allowed to equilibrate for $90 \mathrm{~min}$ and then contracted with $1 \mu \mathrm{M}(-)$ phenylephrine. When the response to the agonist reached a plateau, cumulative concentration-response curves were determined. Effect of $1 \mu \mathrm{M}$ ODQ was evaluated in separate series of experiments in which they was added 5 min before the contraction. $\mathrm{EC}_{50}$ values are the mean of at least 5 determinations. Responses were recorded by an isometric transducer connected to the MacLab System PowerLab.

\subsubsection{Mice, infection and treatment}

Six to eight week old C57BL/6 mice were obtained from Jackson Laboratories (Bar Harbor, ME). All experimental protocols were reviewed and approved by LJBI Institutional Animal Care and Use Committee. Plasmodium berghei ANKA strain expressing the green fluorescent protein (PbA-GFP, a kind donation of MR4, Manassas, VA) was inoculated intraperitoneally ( $1 \times 10^{6}$ parasitized red blood cells) and parasitemia, motor behavior, rectal temperature and weight were checked beginning on day 5 after infection. CM was defined as the presentation of one or more of the following clinical signs of neurological involvement: ataxia, limb paralysis, poor righting reflex, seizures, roll-over, coma. Additional clinical evaluation was performed using a set of six simple behavioral tests, as described [18]. Mice with late stage CM were treated with either amodiaquine (AQ) at $1 \mathrm{mg}$ per mouse, compound $\mathbf{4 0}$ or compound $\mathbf{3 1}$ at molar-equivalent doses (1.4mg and $1.15 \mathrm{mg}$ per mouse, respectively) daily for 5 days. Compound $\mathbf{4 0}$ was prepared in vehicle containaing 20\% DMSO (Sigma, St Louis, MO), 20\% polyethyleneglycol 400 (Sigma) and 60\% saline, and compound $\mathbf{3 1}$ was prepared in saline. AQ was given in the control group in the same vehicle as the test compound. Each mouse received $100 \mu \mathrm{L}$ intraperitoneally. 


\section{Acknowledgments}

This work was supported by a grant from Università degli Studi di Torino, Progetti locali di ricerca 2008.

\section{Appendix. Supplementary data}

Supplementary data associated with this article can be found, in the online version,

\section{References and notes}

[1] World Malaria Report 2008, World Health Organisation, Geneva, 2008.

[2] J. Loscalzo, J.A. Vita (Eds), Nitric Oxide and Cardiovascular System, Humana Press, Totowa, 2000.

[3] J.V. Esplugues, Br. J. Pharmacol. 135 (2002) 1079-1095.

[4] C. Bogdan, Nat. Immunol. 2 (2001) 907-916.

[5] A. Clark, W.C. Cowden, Pharmacol. Ther.99 (2003) 221-260.

[6] K.K. Rockett, M.M. Awburn, W.B. Cowden, I.A. Clark, Infect. Immun. 59 (1991) 3280-3283.

[7] A. Sharma, A. Eapen, S.K. Subbarao, J. Biochem. 136 (2004) 329-334.

[8] U. Galli, L. Lazzarato, M. Bertinaria, G. Sorba, A. Gasco, S. Parapini, D. Taramelli, Eur. J. Med. Chem. 40 (2005) 1335-1340.

[9] P. Sobolewski, I. Gramaglia, J. Frangos, M. Intaglietta, H.C. Van der Heyde, Trends Parasitol. $21(2005)$ 415-422.

[10] a) I. Gramaglia, P. Sobolewski, D. Meays, R. Contreras, J.P. Nolan, J.A. Frangos, M. Intaglietta, H.C. Van der Heyde, Nat. Med. 12 (2006) 1417-1422. b) T. W. Yeo, D. A. Lampah, R. Gitawati, E. Tjitra, E. Kenangalem, Y. R. McNeil, C. J. Darcy, D. L. Granger, J. B. Weinberg, B. Lopansri, R. N. Price, S. B. Duffull, D. S. Celermajer, N. M. Anstey, J. Exp. Med. 204 (2007) 2693-2704. 
[11] P.J. Rosenthal (Ed.), Antimalarial Chemotherapy, Humana Press, Totowa, New Jersey, 2001.

[12] World Health Organisation, WHO Model List of Essential Medicines. http://www.who.int revised on March 2005.

[13] A. Gasco, R. Fruttero, B. Rolando, Mini Rev. Med. Chem. 5 (2005) 217-229.

[14] W. Kurosawa; T. Kan; T. Fukuyama, T. Org. Synth. 79 (2002) 186.

[15] S. Guglielmo, M. Bertinaria, B. Rolando, M. Crosetti, R. Fruttero, V. Yardley, S.L. Croft, A. Gasco, Eur. J. Med. Chem. 44 (2009) 5071-5079.

[16] R. Fruttero, G. Sorba, G. Ermondi, M. Lolli, A. Gasco, Farmaco, 52 (1997) 405-410.

[17] D.C. Warhurst, J.C.P. Steele, I.S. Adagu, J.C. Craig, C. Cullander, J. Antimicrob. Chemother. 52 (2003) 188-193.

[18] P. Cabrales, G.M. Zanini, D. Meays, J.A. Frangos, L.J. Carvalho, Am J Pathol. 176 (2010) 1306-15.

[19] P. Cabrales, G.M. Zanini, D. Meays, J.A. Frangos, L.J. Carvalho, J Infect Dis (in press).

[20] G. Sorba, G. Ermondi, R. Fruttero, U. Galli, A. Gasco, J. Heterocycl. Chem. 33 (1996) 327-334.

[21] L.B. Romanova, M.E. Ivanova, D.A. Nesterenko, L.T. Ermenenko, Russ. Chem. Bull. 43 (1994) 1207-1209.

[22] W.V. Farrar, J. Chem. Soc. (1964) 904-906.

[23] G. Sorba, C. Medana, R. Fruttero, C. Cena, A. Di Stilo, U. Galli, A. Gasco J. Med. Chem. 40 (1997) 463-469.

[24] R. R. Ranatunge, M. E. Augustyniak, V. Dhawan, J. L. Ellis, D. S. Garvey, D. R. Janero, L. G. Letts, S. K. Richardson, M. J. Shumway, A. M. Trocha, D. V. Young, I. S. Zemtseva, Bioorg. Med. Chem. 14 (2006) 2589-2599.

[25] P.G. Baraldi, R. Romagnoli, M. del Carmen Nuñez, M. Perretti, M. J. Paul-Clark, M. Ferrario, M. Govoni, F. Benedini, E. Ongini, J. Med. Chem. 47 (2004) 711-719.

[26] H. Xubo, K.Y. Nguyen, V.C. Jiang, D. Lofland, H.E. Moser, D. Pei, J. Med. Chem. 47 (2004) 4941-4949. 
[27] K. J. Fraunhoffer, D. A. Bachovchin, M. C. White, Org. Lett. 7 (2005) 223-226.

[28] T. Brown, N. J. Gibson, WO/1999/045017.

[29] M.-L. Fontane1, H. Bazin, R. Téoule, Bioconjugate Chem. 4 (1993) 380-385.

[30] E.F. Elslager, S.C. Perricone, F.H. Tendick, J. Med. Chem. 12 (1969) 965-969.

[31] A. Avdeef, J.E.A. Comer, S:J. Thomson, Anal. Chem. 65 (1993) 42-49.

[32] W. Trager, J.B. Jensen, Science 193 (1976) 673-675.

[33] M. Makler, D. Hinrichs, Am. J. Trop. Med. Hyg. 48(2) (1993) 205-210.

[34] D. Monti, N. Basilico, S. Parapini, E. Pasini, P. Olliaro \& D. Taramelli, FEBS Letters 522 (2002) 3-5. 


\section{Figure Captions}

Scheme 1. Preparation of derivatives $3,4,7,12-15$. Reagents and conditions: (a) fuming $\mathrm{HNO}_{3},-15$ ${ }^{\circ} \mathrm{C}$ to RT, 24 h; (b) $\mathrm{EtNH}_{2}$, EtOH, RT; 48 h; (c) $1 \mathrm{~N} \mathrm{HCl;} \mathrm{(d)} \mathrm{ion-exchange} \mathrm{chromatography,}$ Amberlite IRA-400.

Scheme 2. Preparation of 26. Reagents and conditions: (a) $\mathrm{CH}_{3} \mathrm{SO}_{2} \mathrm{Cl}, \mathrm{Et}_{3} \mathrm{~N}, \mathrm{CH}_{2} \mathrm{Cl}_{2}, \mathrm{RT}$; (b) potassium phtalimide, $\mathrm{KI}$ cat., $\mathrm{CH}_{3} \mathrm{CN}$, reflux, $72 \mathrm{~h}$. (c) $\mathrm{KMnO}_{4}$, Acetone $/ \mathrm{H}_{2} \mathrm{O}, 0{ }^{\circ} \mathrm{C}$ to $\mathrm{RT}, 3 \mathrm{~h}$; (d) Acetone, PPTS cat, RT, 18 h; (e) $\mathrm{N}_{2} \mathrm{H}_{4} \cdot \mathrm{H}_{2} \mathrm{O}$, dist. THF, reflux, 24 h; (f) 2-nitrobenzensulfonyl chloride, $\mathrm{Et}_{3} \mathrm{~N}, \mathrm{CH}_{2} \mathrm{Cl}_{2}, 0{ }^{\circ} \mathrm{C}$ to RT, $30 \mathrm{~min}$; (g) EtI, $\mathrm{K}_{2} \mathrm{CO}_{3}$, DMF, $60{ }^{\circ} \mathrm{C}, 10 \mathrm{~h}$; (h) $\mathrm{PhSH}, \mathrm{KOH}$, $\mathrm{CH}_{3} \mathrm{CN}, 0{ }^{\circ} \mathrm{C}$ to $50{ }^{\circ} \mathrm{C}, 4 \mathrm{~h}, \mathrm{~N}_{2}$ atmosphere. (i) $\mathrm{CF}_{3} \mathrm{COOH} / \mathrm{H}_{2} \mathrm{O} 8 / 2$, reflux, $24 \mathrm{~h}$; (j) ion-exchange chromatography, Amberlite IRA-400; (k) fuming $\mathrm{HNO}_{3},-15{ }^{\circ} \mathrm{C}$ to RT, $40 \mathrm{~h}$.

Scheme 3. Preparation of derivatives 28-35. Reagents and conditions: (a) 3, 4, 7, 26, $\mathrm{Et}_{3} \mathrm{~N}, \mathrm{CH}_{3} \mathrm{CN} /$ DMF 1/1, RT, 6 h; (b) $\mathrm{HCl}$ satd $\mathrm{Et}_{2} \mathrm{O}, \mathrm{MeOH}$; (c) 12-15, $\mathrm{Et}_{3} \mathrm{~N}, \mathrm{CH}_{3} \mathrm{CN} / \mathrm{DMF}$ 1/1, RT, 6 h.

Scheme 4. Preparation of derivatives 37, 40. Reagents and conditions: (a) 2-(ethylamino)ethanol, $\mathrm{CH}_{3} \mathrm{CN}$, RT, 20 h; (b) 3-phenyl-4-benzenesulfonyl furoxan, 50\% aq $\mathrm{NaOH}$, dist. THF/DMF, RT, $\mathrm{N}_{2}$ atmosphere (c) 39, $\mathrm{Et}_{3} \mathrm{~N}$, iPrOH/DMF, RT, 24 h; (d) 2-(ethylamino)ethanol, $50 \%$ aq NaOH, dist. THF/DMF, RT, 20 h; $\mathrm{N}_{2}$ atmosphere.

Figure 1. Efficacy of amodiaquine (AQ), compound $\mathbf{4 0}$ and compound $\mathbf{3 1}$ in rescuing mice with late stage CM. A and B: survival curves of of PbA-infected mice with late stage $\mathrm{CM}$ following treatment with: (A) AQ (solid circle) $1 \mathrm{mg}$ per mouse $(\mathrm{n}=12)$ or compound 40 (open square, dashed line) at an equivalent molar dose (1.4 mg per mouse, $\mathrm{n}=12)$ and; (B) AQ (solid circle) $1 \mathrm{mg}$ per mouse $(\mathrm{n}=29$ ) or compound $\mathbf{3 1}$ (open triangle, dashed line) also at an equivalent molar dose (1.15 mg per mouse, $\mathrm{n}=19)$. C and D: parasitemia curves showing the profile of parasite clearance 
of the same treatment groups showed in A and B, respectively. Results in C and D are the mean \pm SEM. 
Table 1. Dissociation constants of the final compounds

\begin{tabular}{cccc}
\hline Compound & $p K_{\mathrm{a} 1}{ }^{\mathrm{a}}$ & $p K_{\mathrm{a} 2}{ }^{\mathrm{a}}$ & $p K_{\mathrm{a} 3}{ }^{\mathrm{a}}$ \\
\hline $\mathbf{2 8}$ & 7.42 & 8.47 & - \\
$\mathbf{2 9}$ & 7.06 & 8.14 & - \\
$\mathbf{3 0}$ & 7.08 & 8.56 & - \\
$\mathbf{3 1}$ & 6.99 & 8.09 & - \\
$\mathbf{3 2}$ & 7.08 & 7.86 & - \\
$\mathbf{3 3}$ & 7.05 & 7.98 & - \\
$\mathbf{3 4}$ & 3.00 & 6.46 & 7.59 \\
$\mathbf{3 5}$ & 3.06 & 6.71 & 7.69 \\
$\mathbf{3 7}$ & 6.18 & 7.66 & - \\
$\mathbf{4 0}$ & 6.12 & 7.68 & - \\
\hline
\end{tabular}

${ }^{\mathrm{a}}$ Determined by potentiometry; S.D. $\leq 0.07$. 
Table 2. Antiplasmodial action and vasodilating ability of the synthesised compounds and reference derivatives

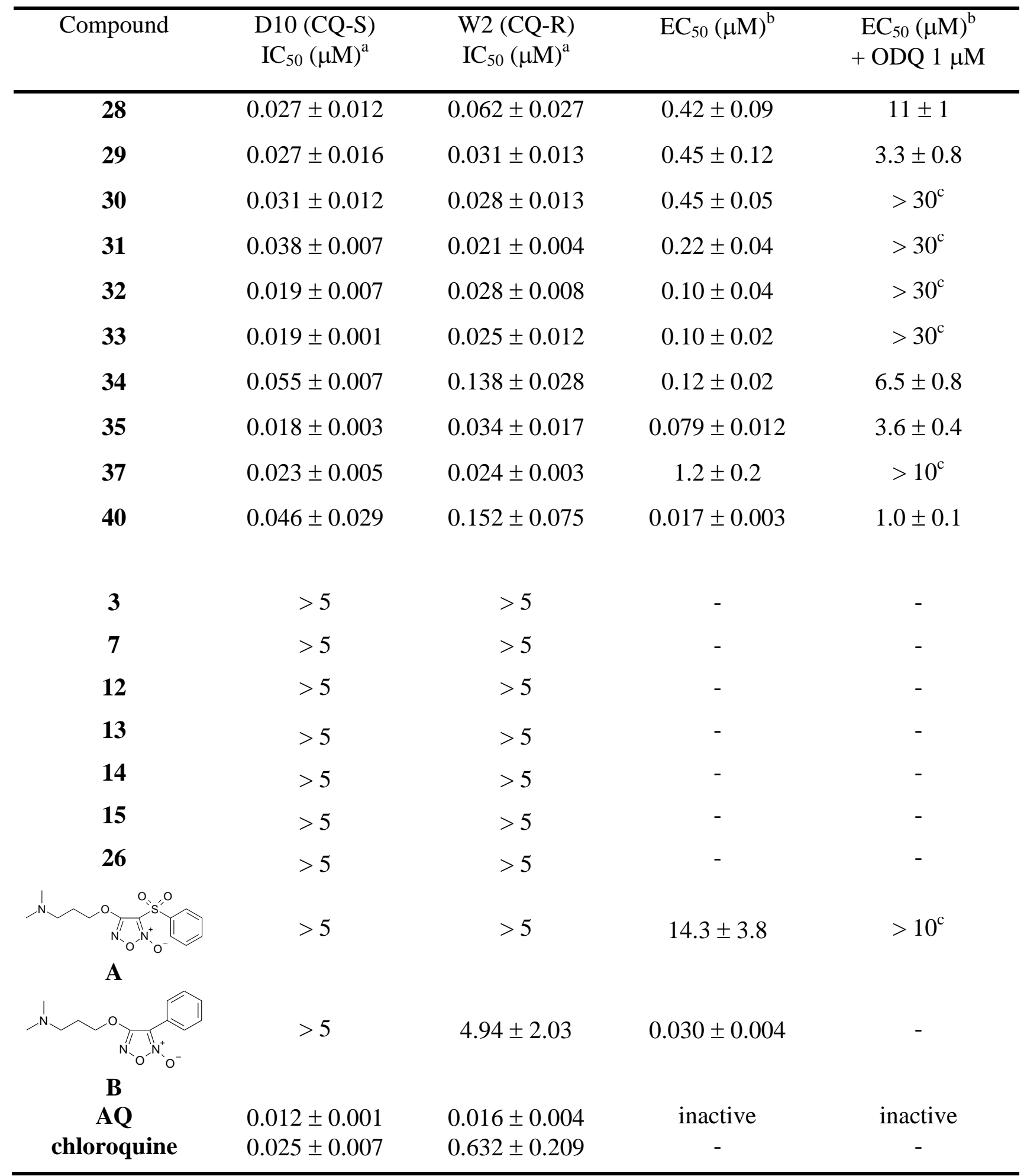

\footnotetext{
${ }^{\mathrm{a}}$ The $\mathrm{IC}_{50}$ represents the $\mu \mathrm{M}$ equivalents of test compounds required to inhibit parasite growth by $50 \%$ (data are expressed as mean $\pm \mathrm{SD}$ ).

${ }^{\mathrm{b}}$ The $\mathrm{EC}_{50}$ represents the $\mu \mathrm{M}$ equivalents of test compounds required to relax the precontracted rat aorta strips by $50 \%$ (data are expressed as means $\pm \mathrm{SE}$ ).

${ }^{c}$ not able to reach $50 \%$ tissue relaxation at the maximum concentration tested.

- = not tested
} 